\title{
Ovarian cytoarchitectual changes following fennel ingestion in senile diabetic albino rat
}

\section{Original Article}

\author{
Hekmat A. Ahmed-Sorour, Fatma S. Abdel Aal, Mona M. Abd-Elgalil \\ Histology Department, Faculty of Medicine for Girls, Al Azhar University, Cairo, Egypt
}

\begin{abstract}
Introduction: Postmenopausal obesity sounds an alarm for women's health, since it serves as a predominant risk factor for many chronic diseases leading to reduced life expectancy and increased health problems. The relation between menopausal status and diabetes mellitus remains controversial. Reproductive tract dysfunction is a recognized consequence of diabetes obesity syndrome (DOS). Therefore, a possible association between obesity, diabetes mellitus and abnormalities of female reproductive function in several respects may occur.Nowadays traditional medicinal plants and spices are commonly used for their possible effects as hypoglycaemic, antidiabetic and folliculogenic agents instead of using synthetic drugs.

Aim: The objective of this study was to evaluate the therapeutic implication of fennel ingestion in ovarian changes in diabetically induced senile rats.

Materials and Methods: A total of 24 senile female albino rats were divided into 4 equal groups: control group, fennel oil receiving group, diabetic group and diabetic/fennel oil ingested group. Treatments were continued for 8 weeks, then ovarian samples were collected from all rats for histological, immunohistochemical and ultra-structural studies. Blood glucose levels were measured to confirm hyperglycemia and to follow the disease progression. Serum analyses for hormonal assay were also estimated

Results: STZ injection caused typical ovarian follicular cysts of variable sizes together with elevation of blood glucose level. Fennel oil administration to diabetes-induced group showed some amelioration in the ovarian structure and blood glucose level.

Conclusion: Fennel essential oil could ameliorate diabetes with its use as a fertility enhancing agent. Fennel has folliculogenesis effect consistent with its use in folk medicine as a fertility enhancing agent.
\end{abstract}

Revised: 09 March 2017, Accepted: 29 September 2017

Key Words: Diabetes mellitus, fennel essential oil, ovary

Corresponding Author: Mona M. Abd-Elgalil, Faculty of Medicine, Alazhar Universty, Cairo, Egypt, Tel.: 01019003955, E-mail: medicalmona2009@yahoo.com.

ISSN: $1110-0559$, Vol. 40, No.4

\section{INTRODUCTION}

Postmenopausal weight gain is a symptom that cannot really be controlled, where losing weight becomes almost impossible. Postmenopausal obesity sounds an alarm for women's health, since it serves as a predominant risk factor for many chronic diseases such as metabolic syndrome. Furthermore postmenopausal obesity is considered a chronic disease that has severe consequences on physical and psychological health, leading to reduced life expectancy and increased health problems ${ }^{[13]}$.

Diabetes mellitus is increasing rapidly in most parts of the world. It is becoming a common epidemic disorder and the third killer of mankind health along with cancer, cardiovascular and cerebrovascular diseases ${ }^{[4-6]}$.

The relation between menopausal status and diabetes mellitus remains controversial. However, clinical trials suggest that menopause would speed the progression to diabetes. This can be explained by the fact that changing estrogen and progesterone levels in postmenopausal women combined with postmenopausal weight gain affect insulin sensitivity and glucose metabolism making it more difficult to control ${ }^{[1,7,8]}$.

Post-menopausal obesity and lipid overload might be associated with tissue damage and organ dysfunction. Reproductive tract dysfunction is a recognized consequence of diabetes obesity syndrome (DOS) ${ }^{[9-11]}$ stated that in both humans and experimental animals, utero-ovarian function, and metabolic parameters are altered in response to Type II diabetes. Therefore, a possible association between obesity, diabetes mellitus and abnormalities of female reproductive function in several respects may occur.

Herbal medicines have been widely utilized as effective remedies for the prevention and treatment of multiple 
health conditions. Nowadays there is an increasing interest towards the active role of herbal remedies for use in scientific research. Extracts of medicinal plants are replacing synthetic drugs. Traditional medicinal plants and spices are commonly used for their possible effects as hypoglycaemic, anti-diabetic and folliculogenic agents instead of using synthetic drugs ${ }^{[12-14]}$.

We aimed to investigate the changes in ovarian cytoarchitectural, immunohistochemical endocrinal expression and related plasma hormonal levels in diabetes induced senile rats. Moreover, therapeutic implication of fennel ingestion will also be evaluated.

\section{MATERIALS AND METHODS}

Twenty four senile female albino rats (280-330) gm aging 18-20 months were used in the current experiment rats were divided equally into 4 groups: each containing 6 rats. GI was the Control group. GII-fennel oil group included animals which were daily administered fennel oil by an orogastric tube at a dose of $2 \mathrm{ml} / \mathrm{kg}$ body weight "bw"[13] (Fennel oil was purchased from Kato Aromatic Company, Giza, Egypt). In GIII-diabetic group animals received an intra-peritoneal (IP) single dose of freshly prepared streptozotocin (STZ) at a dose $60 \mathrm{mg} / \mathrm{kg}$ bw dissolved in $0.01 \mathrm{M}$ citrate buffer ${ }^{[15]}$ (STZ was purchased from Sigma Company, St. Louis, Mo, USA). GIV-diabetic/ fennel oil group rats were given STZ and fennel oil as the previously mentioned regimens. Blood glucose level was measured on the 3rd day of STZ injection following overnight fasting in order to insure diabetes.

The treatments were started on the 3rd day after STZ injection which was considered the first day of experiment. The treatments were continued for 8 weeks. All the experimental animals were daily fed on a balanced diet till the end of this study. The animals of all groups were weighed individually at the beginning of the experiment and at the end just before collecting samples. Blood glucose levels were measured in overnight ( 16 hours) fasted rats on the 3 rd day after STZ injection and at the end of the experiment. For histological, immunohistochical and ultrastructural studies rats were lightly anaesthetized with ether and blood samples were collected immediately in sterile tubes from the orbital sinus of each rat using a heparinized capillary tube. The separated serum samples were analyzed for hormonal assay Estradiol (E2), Progesterone and Luteinizing Hormone $(\mathrm{LH})^{[16]}$. The hormonal levels were measured by an automated electrochemiluminescence immunoassay (ECL) technology using Roche cobas E411 immunoassay analyzer ( Mannheim, Germany).

Ovarian samples were collected, fixed in $10 \%$ formalin for 2 days ${ }^{[17]}$ and processed for paraffin $4 \mu \mathrm{m}$ thick sections. Sections were stained with haematoxyline and eosin (H\&E) for routine histological examination and Masson's trichrome stain, for staining collagen fibers ${ }^{[18]}$.
For electron microscopic preparation, small ovarian pieces from 2 animals of the control, diabetic and diabetic fennel groups were fixed immediately in $5 \%$ glutaraldehyde for $24 \mathrm{~h}$. The specimens were processed, ultrathin sections were prepared ${ }^{[19]}$ and examined using an electron microscope JEOL, TEM 1010 (Tokyo, Japan) in the electron microscopic unit of the Regional Center for Mycology and Biotechnology (RCMB), Al Azhar university.

\section{Immunohistochemical study}

The immunohistochemical technique used to localize the distribution of estrogen receptors alpha $(\mathrm{ER} \alpha)$ in the various ovarian cell types ${ }^{[20]}$.

Paraffin sections were deparaffinized with xylene and rehydrated in graded series of ethanol. The process of antigen retrieval was performed in phosphate buffered saline (PBS) bath. Endogenous peroxidase activity was blocked using hydrogen peroxide for 10-15 minutes at $37^{\circ} \mathrm{C}$. Tissue sections were washed gently 3 times with PBS for 2 minutes and then $100 \mu$ of primary Ab mouse monoclonal antibodies was applied to each section. Sections were incubated at room temperature in moist chamber for 30-60 minutes. Tissue sections were rinsed 3 times with PBS for 2 minutes. After addition of biotinylated secondary $\mathrm{Ab}$ " $100 \mu \mathrm{l}$ ", all sections were incubated at room temperature in moist chamber for 10 minutes. Sections were gently washed with buffer and kept in the buffer bath in a humid chamber for 2 minutes. A sufficient amount of streptavidin biotin peroxidase $(100 \mu \mathrm{l})$ was then added to completely cover tissue and incubated for $10 \mathrm{~min}$ at room temperature in moist chamber followed by washing. Peroxidase-compatible chromogen (DAB) mixture was added to the sections and incubated for 515- min followed by washing in distilled water and counterstaining with Meyer's hematoxylin for 1-3 minutes ${ }^{[21]}$. Slides were washed in tap water and were rapidly dehydrated with graded series of alcohol, cleared in xylol and mounted with cover-slips.

\section{Statistical Analysis}

Data of body weight, blood glucose and serum hormonal levels of Estradiol E2, Progesterone and Luteinizing Hormone LH were computerized and expressed as mean \pm standard deviation "SD" for statistical analysis. Statistical studies were applied using "T" and "ANOVA" tests. Statistical significance level was defined as $P \leq 0.05$.

\section{RESULTS}

\section{Histological results H\&E stain (Figs. 1-3)}

Light microscopic examination of ovarian tissues of the control group (GI) demonstrated single layer of 
flattened ovarian surface epithelium with flattened nuclei overlying the tunica albuginea. Corpora lutea bulged into the ovarian surface giving it a lobulated appearance. The ovarian medulla contained richly vascularized loose connective tissue with many relatively large contorted blood vessels and interstitial glandular cells. The main bulk of corpus luteum was formed of small groups of large granulosa lutein cells that were surrounded by small theca lutein cells which had small oval or flattened nuclei. Rich network of blood capillaries were observed in-between the granulosa lutein cells.

Examination of the ovarian sections of fennel group (GII) revealed various kinds of growing follicles at different developmental stages, multilaminar primary follicles, secondary follicles and Graafian follicles in addition to corpora albicans and corpora lutea which appeared bulging into the ovarian surface giving it a lobulated appearance. Richly vascularized loose connective tissue with many relatively large blood vessels and interstitial cells within the ovarian medulla were observed. Granulosa lutein cells were surrounded by small theca lutein cells that appeared more or less as control. Blood capillaries lined with flattened endothelial cells were noticed in between the large graulosa cells of corpus luteum.

The ovarian sections of the diabetic group (GIII) revealed obvious structural changes in the form of typical follicular cysts of variable size. Reduction or even absence of corpora lutea in the sections with no other stages of follicular growth was observed. Dilated congested blood vessels within the ovarian medulla were also observed. Abnormal corpus luteum with vacuolated granulosa lutein cells that appeared enlarged, irregular in shape were mostly showed prominent widespread random distribution of cytoplasmic vacuoles. Mononuclear cells infiltration in the form of lymphocytes and neutrophils were found within blood capillaries in between granulosa lutein cells.

The examination of the ovarian sections of Diabetic/ fennel group (GIV) revealed prominent structural improvement when compared to the diabetic-only group. Various kinds of growing follicles at different developmental stages, multilaminar primary and secondary follicles appeared bulging into the ovarian surface giving it a lobulated appearance. Cellular destruction and vacuolation were mildly noticed mainly near peripheral area of granulosa lutein cells in corpus luteum of this group.

\section{Masson's trichrome stain (Fig. 4)}

Masson's trichrome stained sections of control group (GI) revealed a well developed thin layer of tunica albuginea beneath the surface epithelium. Collagen fibers were oriented more or less parallel to the ovarian surface.
Delicate collagen fibers admixed with ground substance with normal density and distribution of collagen fibers around blood vessels within the ovarian medulla were observed. Corpora lutea were observed with delicate collagen fibers in between the cells.

Sections of the fennel group (GII) showed a well developed thin layer of the tunica albuginea beneath the surface epithelium. Delicate collagen fibers admixed with ground substance and around blood vessels were observed within the ovarian medulla. Corpus luteum was observed with delicate collagen fibers in between the cells.

Sections of the Diabetic group (III) revealed increase of the density and distribution of the collagenous fibers within the ovarian medulla. However, there was slight reduction in the distribution of collagenous fibers in the tunica albuginea beneath the germinal epithelium.

Diabetic/fennel group (IV) sections revealed delicate collagen fibers admixed with ground substance and around blood vessels were within the ovarian medulla. They appeared more or less similar to controls. Corpus albicans appeared as a mass of delicate collagenous connective tissue, with few cells within the ovarian cortex. Well-developed thin layer of collagen fibers in the tunica albuginea was observed.

\section{Immunohistochemical results (Fig. 5)}

Examination of the control group (GI) showed strong brown immunohistochemical granular reaction of ERa among the surface flattened epithelium and granulosa lutein cells of corpus luteum.

Fennel oil receiving group (GII) showed high level of cytoplasmic expression of ER $\alpha$ among ovarian surface cubical epithelium and granulosa lutein cells of corpus luteum.

Diabetic group (GIII) showed weak cytoplasmic expression of ER $\alpha$ among ovarian surface epithelial cells and among the remaining membrana granulosa cells of follicular cyst.

Diabetic/fennel group (GIV) showed strong immunohistochemical granular reaction among the surface cubical cells and granulosa lutein cells of corpus luteum which appeared more or less as in the control.

\section{Electron microscopic results}

Examination of control group (GI) ovarian sections revealed corpora lutea with large polyhedral granulosa lutein cells and blood capillaries in between. Granulosa cells had euchromatic nuclei with irregular contour. These cells were surrounded by polyhedral theca lutein interna cells which had euchromatic oval nuclei, with 
blood capillaries in-between them that contained red blood corpuscle .Collagen fibers in different directions separating the granulosa cells from each other and from the surrounded theca cells (Fig. 6).The granulosa lutein cells cytoplasm contained mitochondria with tubular cristae, lysosomes that appeared as smooth-walled vesicles enclosed slightly electron-opaque material, flattened cisternae of rough endoplasmic reticulum and Golgi complex consisted of orderly stacked flattened saccules. Cross and longitudinal sections of collagen fibers cut in different directions with a characteristic regular periodicity separating the granulosa cells from each other (Fig. 7) were also noticed.

Electron microscopic sections of diabetic group (GIII) showed marked degenerative changes in granulosa lutein cells in the form of accumulation of numerous variable sized electron lucent lipid droplets which mostly filled the whole cytoplasm with heterochromatic nuclei and dense chromatin clumps (Fig. 8). Some of their nuclei showed increase spacing of nuclear envelope. Dilated cisternae of rough endoplasmic reticulum and multiple apparently abnormal degenerated oval to rounded mitochondria, with disrupted cristae and loss of internal organization were scattered within the cytoplasm (Fig. 9).Dilated Golgi complex in vesicular and tubular forms was clearly observed (Fig. 10). Multivesicular bodies and closely packed vesicles were apparently increased within the luteal cell cytoplasm. Such vesicles were smooth membrane bounded, varied greatly in size and appeared empty or enclosing electron opaque material (Fig. 11).

Electron microscopic examination of Diabetic/ fennel group (GIV) showed few variable sized electron lucent lipid droplets in the cytoplasm of polyhedral granulosa lutein cells, surrounded by theca lutein interna cells with relatively euchromatic elongated flattened nuclei and flattened theca lutein externa (Fig. 12). The cytoplasm contained also free ribosomes, parallel stacks of flattened cisternae of rough endoplasmic reticulum and multiple oval apparently normal mitochondria with tubular cristae.
Theca lutein interna contained few lipid droplets in their cytoplasm and were separated from the granulosa lutein cells by thin layer of collagen fibers cut in different direction (Fig. 13).

\section{Statistical results}

At the beginning of the experiment the mean values of initial body weight of all studied groups were nearly similar with no statistically significant difference.

At the end of the experiment, diabetic group (III) showed the least recorded mean of final body weight when compared to the other experimental groups, followed by diabetic/fennel oil ingested group (IV). However, the highest mean was among the fennel oil ingested group (II). All these data were presented in table (1) and histogram (1).

On the 3rd day following STZ injection, the fasting blood glucose levels were within normal in groups I and II. However, the highest mean of blood glucose was recorded in groups III and IV respectively.

At the end of the experiment, Group III showed the highest level of blood glucose if compared to the other experimental groups. The blood glucose level was within normal in groups II. But Group IV showed decrease of the blood glucose level compared with the diabetic group. All these data were presented in table (2) and histogram (2).

Serum hormone levels showed a statistically significant increase in the mean values of both serum Estradiol and Progestron levels, with the highest mean values recorded among group (IV). While, the least means were recorded among diabetic group (III) that showed at the same time the highest mean value of serum LH level. All these data were represented in table (3) and illustrated in histogram (3).

Table 1: The mean values of initial and final body weight (g) among all rats of the experimental groups.

\begin{tabular}{|c|c|c|c|c|c|c|}
\hline Items & $\begin{array}{c}\text { Group(I) } \\
\mathrm{N}=6\end{array}$ & $\begin{array}{c}\text { Group(II) } \\
\mathrm{N}=6\end{array}$ & $\begin{array}{c}\text { Group(III) } \\
\mathrm{N}=6\end{array}$ & $\begin{array}{c}\text { Group(IV) } \\
\mathrm{N}=6\end{array}$ & $\begin{array}{c}\text { Test of } \\
\text { significance }\end{array}$ & $P$ \\
\hline $\begin{array}{l}\text { Initial weight } \\
\text { mean }(g+S D)\end{array}$ & $291.6 \pm 18$ & $295 \pm 26$ & $293 \pm 20$ & $282 \pm 16$ & $\begin{array}{c}\text { ANOVA } \\
\mathrm{F}=0.5\end{array}$ & 0.7 \\
\hline $\begin{array}{l}\text { Final weight } \\
\text { mean }(g+S D)\end{array}$ & $338 \pm 13$ & $349.5 \pm 25$ & $230 \pm 32$ & $315 \pm 14$ & $\begin{array}{c}\text { ANOVA } \\
\mathrm{F}=35\end{array}$ & $0.000 *$ \\
\hline
\end{tabular}

$\mathrm{SD}=$ is the standard deviation.

$\mathrm{N}=$ Number of animals

$*=P \leq 0.05=$ Significant

$P>0.05=$ Non significant 
Table (2): The mean values of initial and final blood glucose levels ( $\mathrm{mg} / \mathrm{dl})$ among rats of all experimental groups

\begin{tabular}{|c|c|c|c|c|c|c|}
\hline Items & $\begin{array}{c}\text { Group(I) } \\
\mathrm{N}=6\end{array}$ & $\begin{array}{c}\text { Group(II) } \\
\mathrm{N}=6\end{array}$ & $\begin{array}{c}\text { Group(III) } \\
\mathrm{N}=6\end{array}$ & $\begin{array}{c}\text { Group(IV) } \\
\mathrm{N}=6\end{array}$ & $\begin{array}{c}\text { Test of } \\
\text { significance }\end{array}$ & $P$ \\
\hline $\begin{array}{l}\text { Initial glucose } \\
\text { level } \\
\text { mean (mg / dl) }\end{array}$ & $89 \pm 10$ & $96 \pm 9$ & $301 \pm 31$ & $329 \pm 49$ & $\begin{array}{c}\text { ANOVA } \\
\mathrm{F}=111\end{array}$ & $0.000^{*}$ \\
\hline $\begin{array}{l}\text { Final glucose } \\
\text { level } \\
\text { mean }(\mathrm{mg} / \mathrm{dl})\end{array}$ & $107 \pm 9$ & $80 \pm 8.8$ & $377 \pm 26$ & $187.5 \pm 10$ & $\begin{array}{c}\text { ANOVA } \\
\mathrm{F}=460\end{array}$ & 0.000 \\
\hline
\end{tabular}

$\mathrm{N}=$ Number of animals

$*=P \leq 0.05=$ Significant

$P>0.05=$ Non significant

Table 3: The mean values of serum hormone levels of Estradiol ( $\mathrm{pg} / \mathrm{ml})$, Progesterone (pg/ml) and Luteinizing Hormone (LH) (miu/ml) among rats of all experimental groups .

\begin{tabular}{|c|c|c|c|c|c|c|}
\hline Items & $\begin{array}{c}\text { Group(I) } \\
\mathrm{N}=6\end{array}$ & $\begin{array}{c}\text { Group(II) } \\
\mathrm{N}=6\end{array}$ & $\begin{array}{c}\text { Group(III) } \\
\mathrm{N}=6\end{array}$ & $\begin{array}{c}\text { Group(IV) } \\
\mathrm{N}=6\end{array}$ & $\begin{array}{c}\text { Test of } \\
\text { significance }\end{array}$ & $P$ \\
\hline $\begin{array}{l}\text { LH mean } \\
(\mathrm{miu} / \mathrm{ml})\end{array}$ & $0.02 \pm 0.01$ & $0.013 \pm 0.005$ & $0.071 \pm 0.044$ & $0.013 \pm 0.005$ & $\begin{array}{c}\text { ANOVA } \\
\mathrm{F}=3.4\end{array}$ & $0.04 *$ \\
\hline $\begin{array}{l}\text { Estradiol } \\
\text { mean }(\mathrm{pg} / \mathrm{ml})\end{array}$ & $16 \pm 2.8$ & $20.4 \pm 3.6$ & $14.6 \pm 2.5$ & $21.4 \pm 5$ & $\begin{array}{c}\text { ANOVA } \\
\mathrm{F}=8.6\end{array}$ & $0.001 *$ \\
\hline $\begin{array}{l}\text { Progestron } \\
\text { mean }(\mathrm{pg} / \mathrm{ml})\end{array}$ & $17 \pm 3$ & $24.5 \pm 6.8$ & $6.6 \pm 1.4$ & $24 \pm 6.3$ & $\begin{array}{c}\text { ANOVA } \\
\mathrm{F}=18\end{array}$ & $0.000 *$ \\
\hline
\end{tabular}

$\mathrm{N}=$ Number of animals

$*=\mathrm{P} \leq 0.05=$ Significant

Luteinizing Hormone was of non significant value in groups (II,IV) $(P>0.05)$

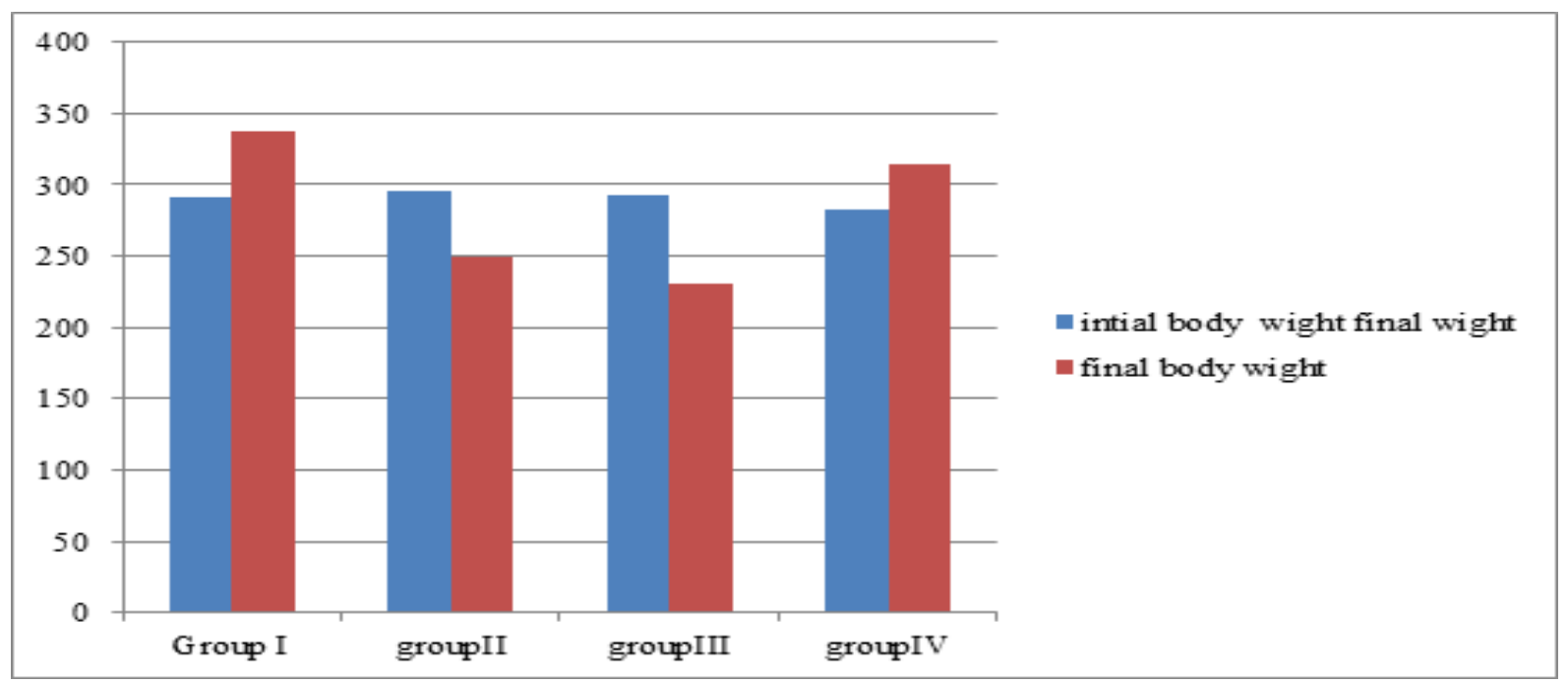

Histogram 1: The mean values of initial and final body weight $(\mathrm{g})$ among all rats of the experimental groups. 


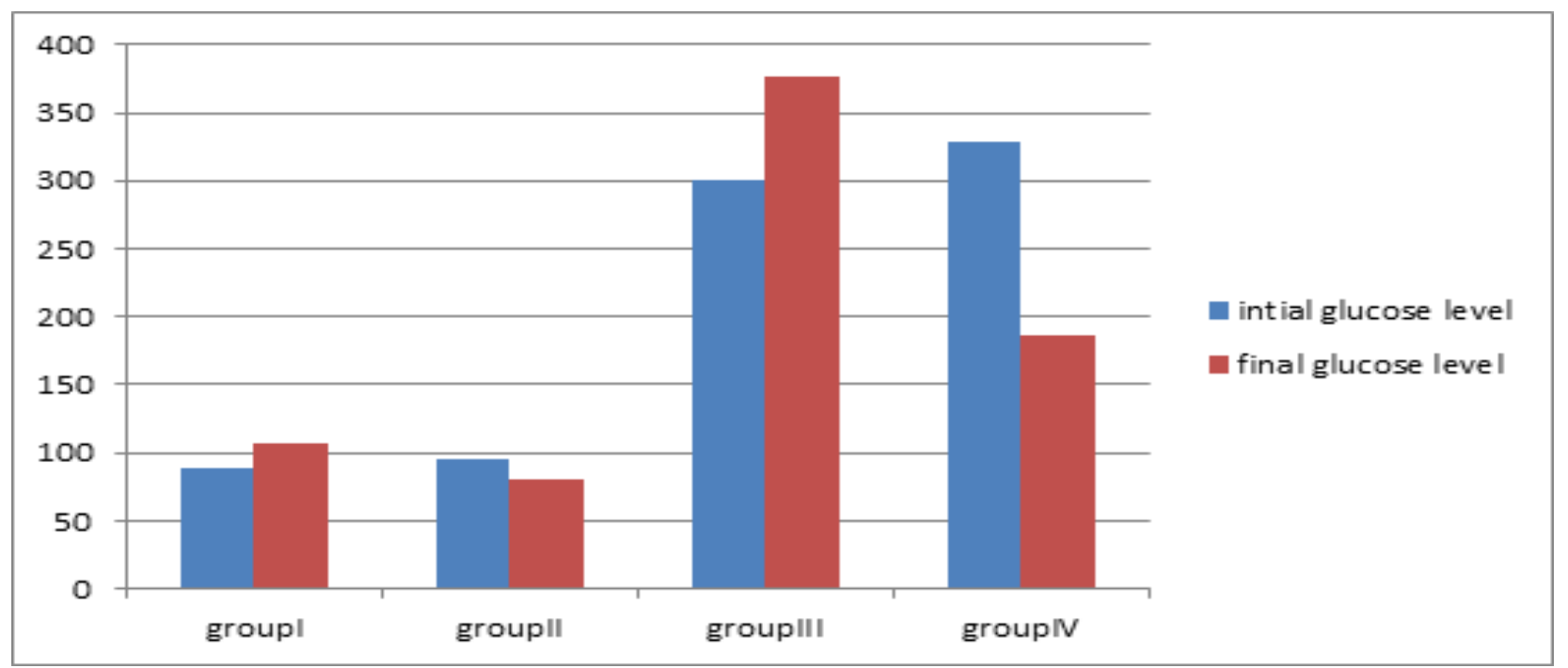

Histogram 2: The mean values of initial and final fasting blood glucose level (mg/dl) among all rats of the experimental groups.

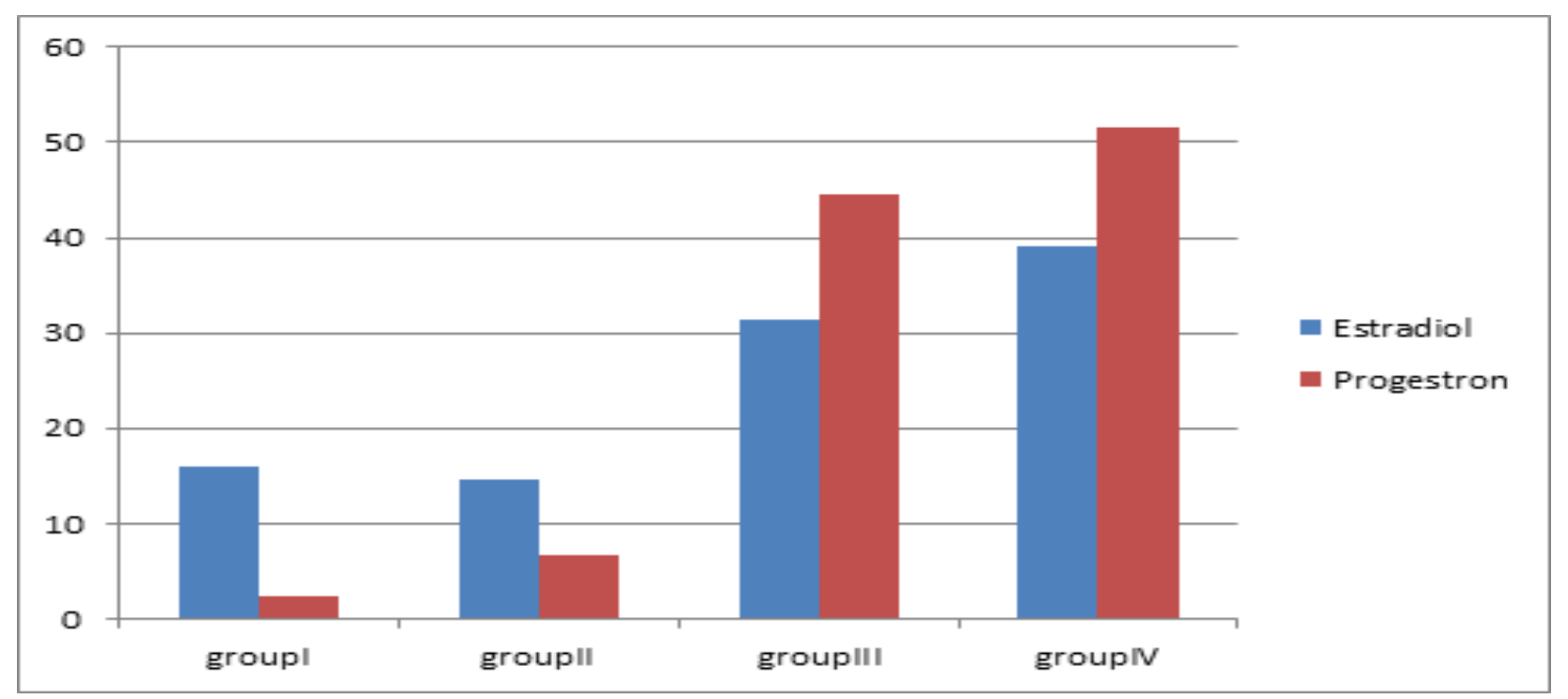

Histogram 3: The mean values of serum hormone levels Estradiol (E2) (pg/ml) and Progesterone (pg/ml) among rats of all experimental groups at the end of 8 th week.

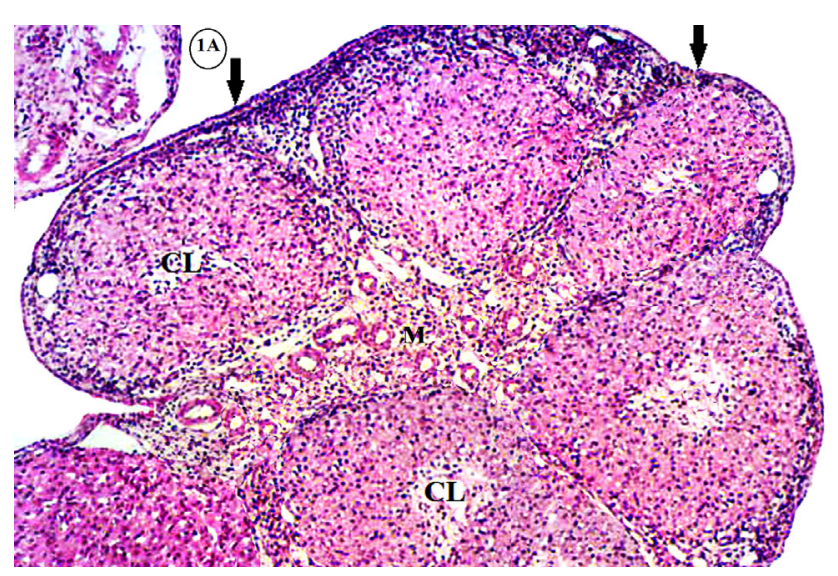

Fig. 1A: Showing multiple corpora lutea (CL) bulging into the ovarian surface giving it a lobulated appearance and a surface epithelium, $(\mathbf{)}$ ) overlying thin layer of tunica albugenia. Numerous blood vessels in the ovarian medulla $(\mathrm{M})$ are seen.

Control H\&E X100

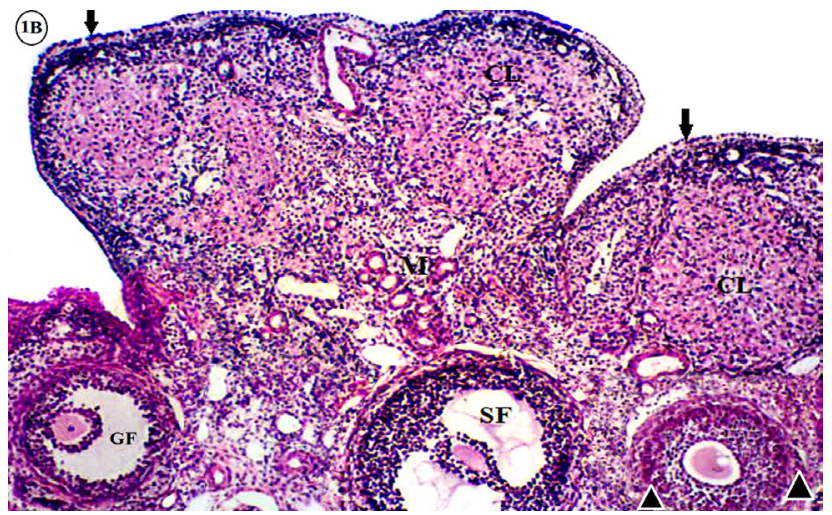

Fig. 1B: Showing corpora lutea (CL), multilaminar primary follicles ( $\boldsymbol{\Delta})$, secondary follicle (SF) and Graafian follicle (GF) within the ovarian cortex and surface epithelium overlying tunica albugenia $(\downarrow)$. Richly vascularized loose connective tissue and interstitial cells within the ovarian medulla $(\mathrm{M})$ are seen.

Fennel H\&E X100 


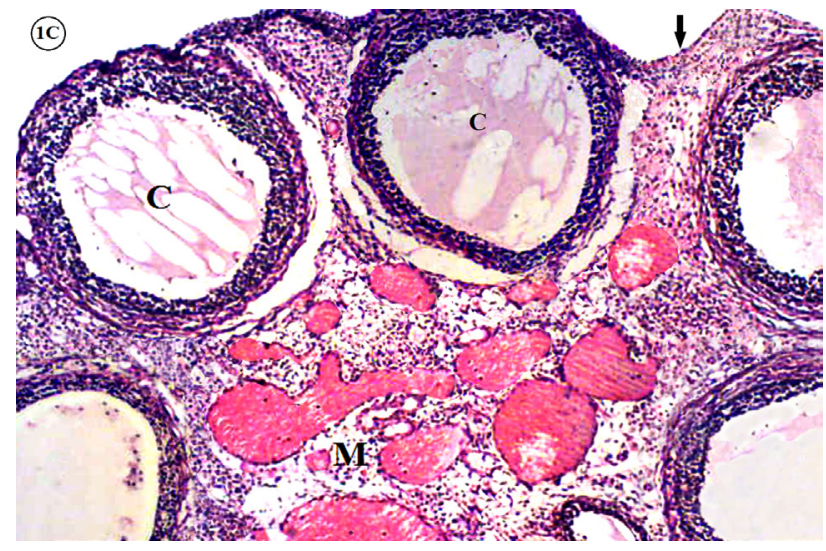

Fig. 1C: Showing typical follicular cysts $(C)$ of variable sizes bulging into the ovarian surface giving it a lobulated appearance. Many dilated congested blood vessels within the ovarian medulla (M) are seen. Surface epithelium overlying a very thin layer of tunica albugenia $(\downarrow)$

Diabetic H\&E X100

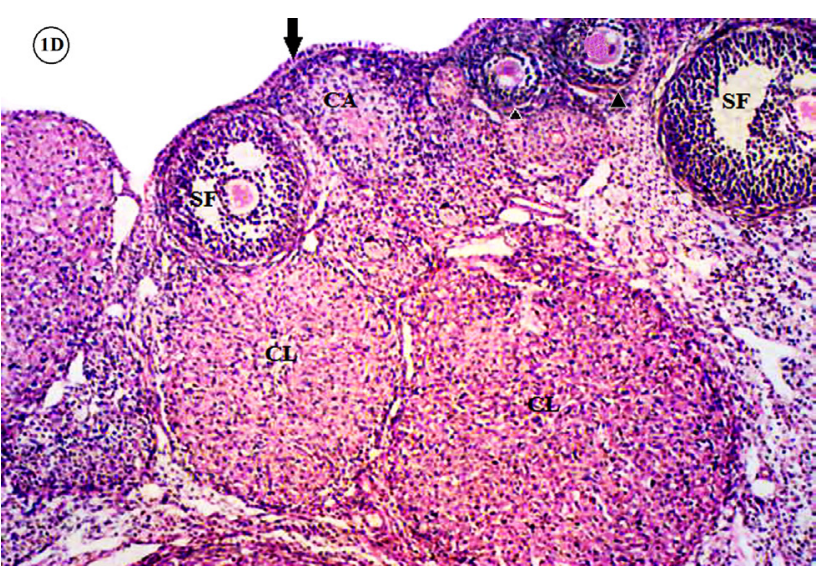

Fig. 1D: Showing corpora lutea (CL), multilaminar primary follicles $(\boldsymbol{\Delta})$ and secondary follicles (SF). Surface epithelium overlying a thin layer of tunica albuginea

Diabetic/Fennel H\&E X100

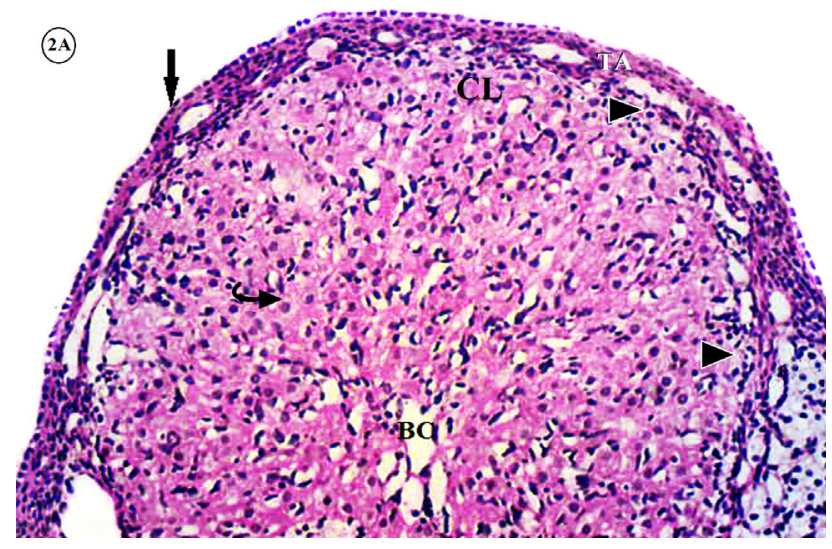

Fig. 2A: Showing part of corpus lutem (CL) in which granulosa lutein cells $(\longrightarrow)$ appear with rich network of blood capillaries (BC) in-between them. Small theca lutein cells are seen surrounding oranulosa lutein cells $(\triangleright)$. Flattened surface epithelium $(\downarrow)$ overlying thin layer of tunica albugenia (TA) is observed.

Control H\&EX200

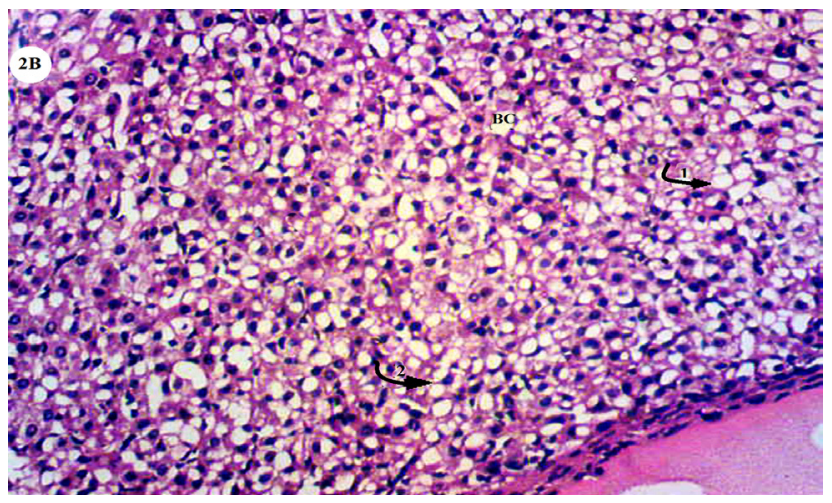

Fig. 2B: Showing part of corpus luteum with vacuolated granulosa lutein cells and rich network of blood capillaries (BC) in-between them. Some granulosa lutein cells are occupied by large cytoplasmic vacuoles with peripheral displacement of the nucleus $(\overleftrightarrow{\longrightarrow})$ other cells have multiple intracytoplasmic vacuoles with centrally located nuclei $(\stackrel{2}{\longrightarrow})$.

Diabetic H\&EX200

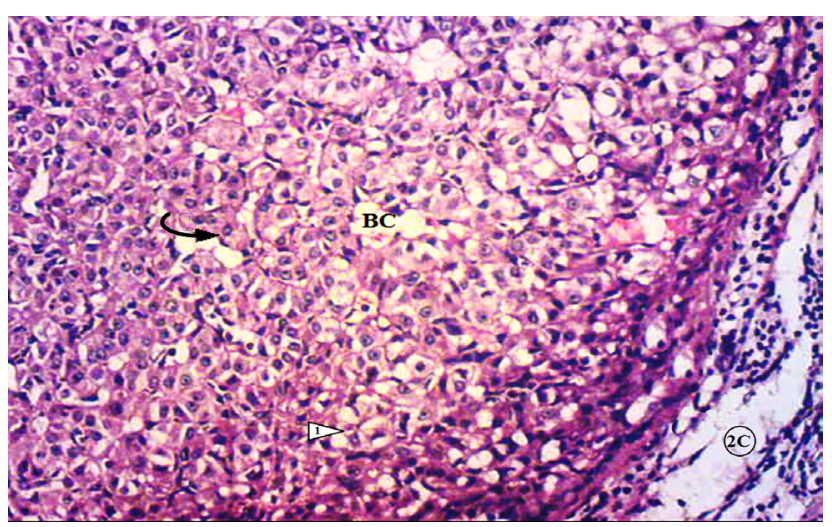

Fig. 2C: Showing part of corpus luteum in which most granulosa lutein cells appear normal as large polygonal cells with eosinophilic cytoplasm and centrally located round nuclei $(\longrightarrow)$ with rich network of blood capillaries (BC). Cells with vaculated cytoplasm (1p) near peripheral area of corpous luteim were also observed.

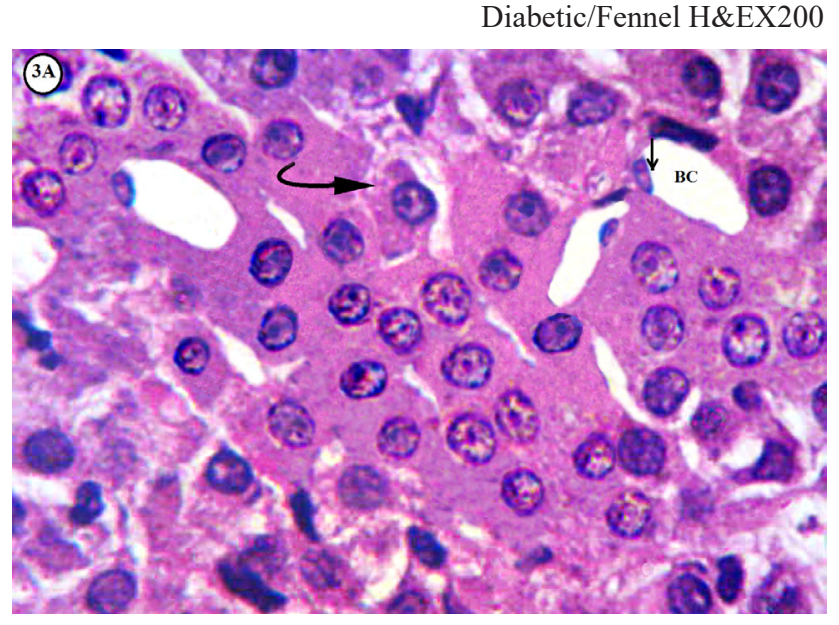

Fig. 3A: Showing large polygonal granulosa lutein cells with eosinophilic cytoplasm and large round vesicular nuclei $(\longleftrightarrow)$ Fattened endothelial cells $(\downarrow)$ lining blood capillaries (BC) inbetween the granulosa lutein cells are notice.

Control H\&EX400 


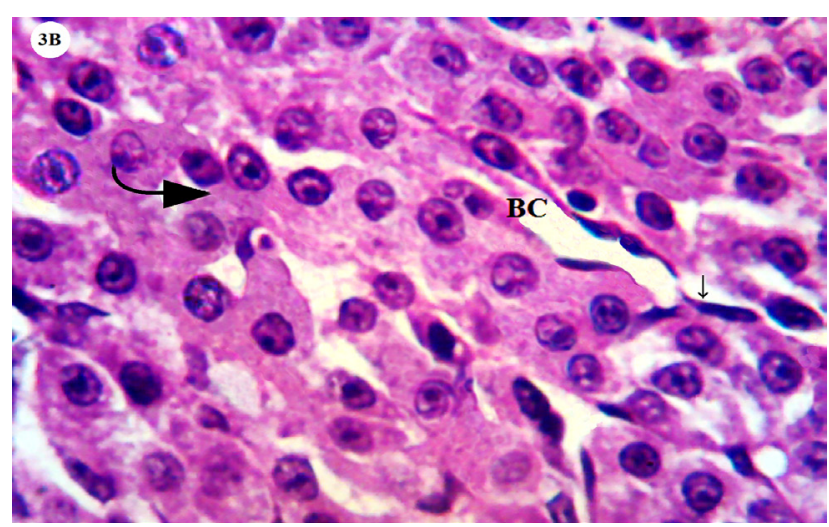

Fig. 3B: Showing large polygonal granulosa lutein cells with eosinophilic cytoplasm and large round vesicular nuclei $(\longrightarrow)$ Notice, flattened endothelial cells ( (BC) in-between the granulosa lutein cells.

Fennel H\&EX400

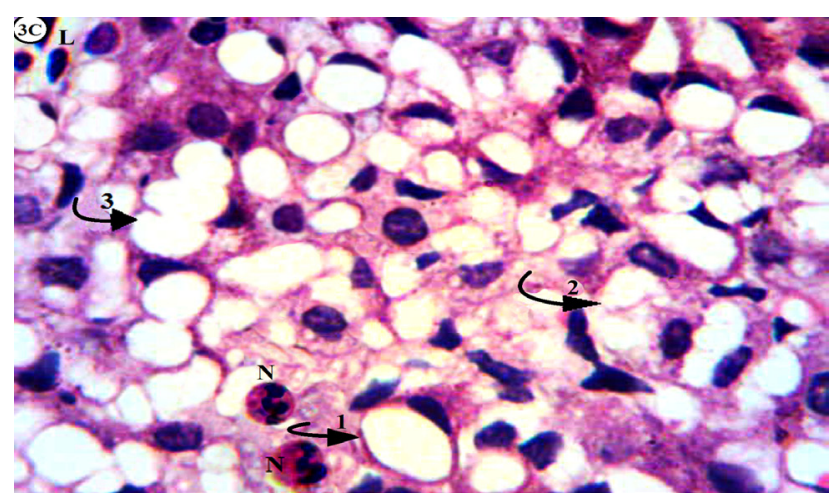

Fig. 3C: Showing some enlarged granulosa lutein cells appear occupied by large cytoplasmic vacuoles with peripheral displacement of the nucleus $(\vec{\longrightarrow})$, other cells have multiple intracytoplasmic vacuoles with centrally located deeply stained nuclei ( $\stackrel{(}{\longrightarrow})$. Notice, some vacuoles coalesce with each other $\left({ }^{(}\right)$). Lymphocytes $(\mathrm{L})$ and neutrophils $(\mathrm{N})$ with segmented nucleus are seen within blood capillaries (BC) in between granulosa lutein

Diabetic H\&EX400

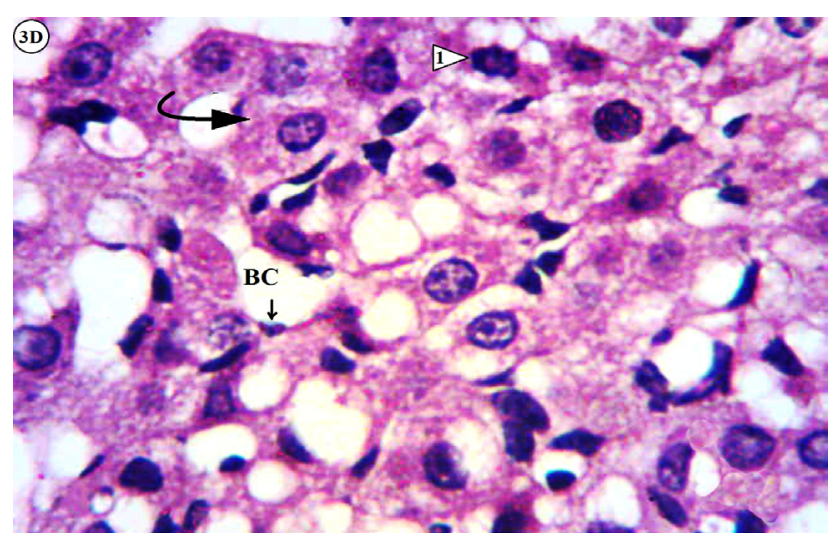

Fig. 3D: Showing large polygonal granulosa lutein cells with eosinophilic cytoplasm and large round vesicular nuclei $(\longrightarrow)$ Notice, some granulosa lutein cells occupied by multiple small intracytoplasmic vacuoles with centrally located rounded nuclei (lp). Flattened endothelial cells, $\downarrow$ ) lining blood capillaries (BC) are seen in-between the granulosa lutein cells.

Diabetic/Fennel H\&EX400

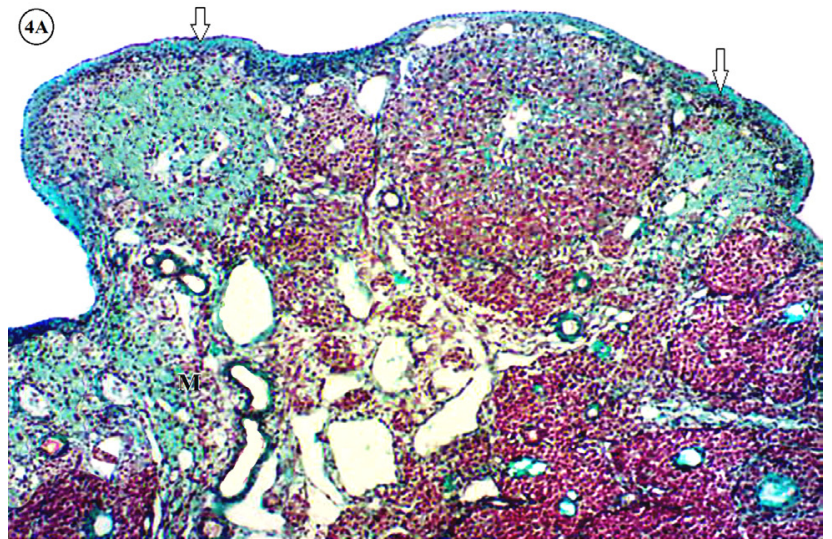

Fig. 4A: Showing well developed layer of collagenous fibers in tunica albuginea $\Omega$, beneath the surface epithelium. Delicate collagen fibers admixed with ground substance are observed within ovarian medulla (M). Notice, normal density and distribution of collagen fibers around medullary blood vessels.

Control Masson's trichrome x100

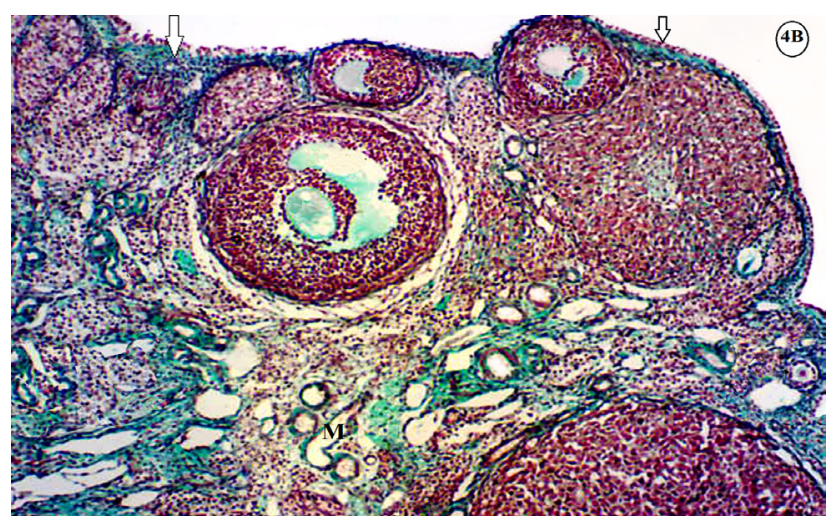

Fig. 4B: Showing well developed layer of collagenous fibers in tunica albuginea $(\mathbb{8}$, beneath the surface epithelium. Delicate collagen fibres admixed with ground substance are observed within ovarian medulla (M) with normal density and distribution of collagen fibers around medullary blood vessels.

Fennel Masson's trichrome x100

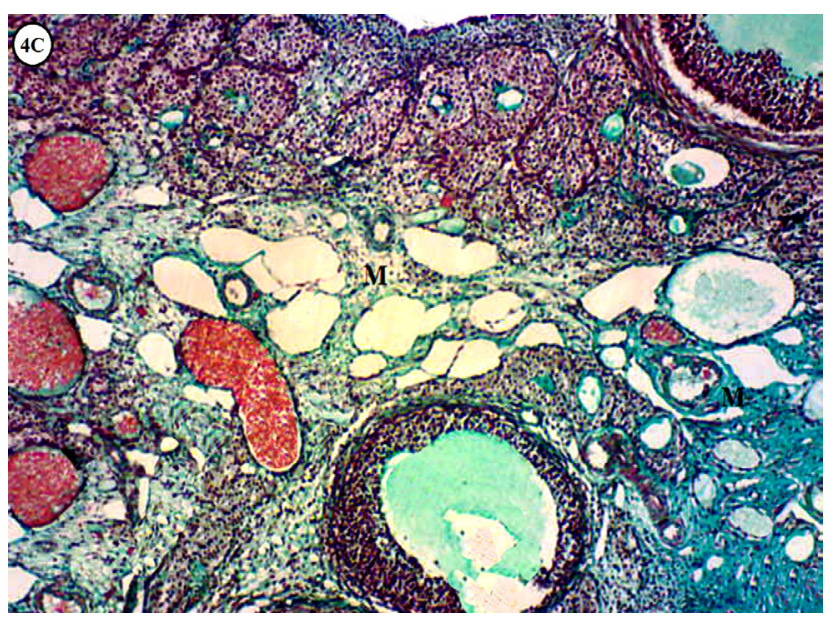

Fig. 4C: Showing increase in the density and distribution of the collagenous fibers within ovarian medulla $(\mathrm{M})$ which contains many dilated congested blood vessels.

Diabetic Masson's trichrome x100 


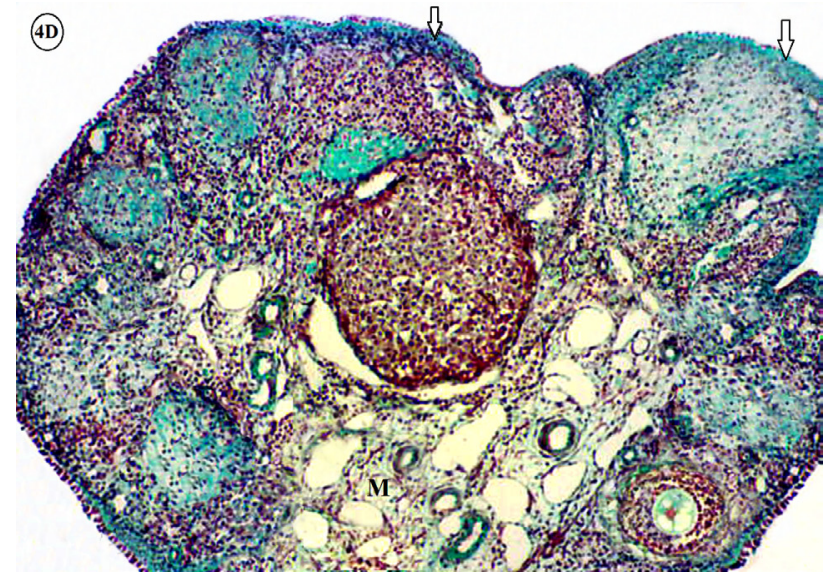

Fig. 4D: Showing: well developed layer of collagenous fibers in tunica albuginea ( 8 , beneath the surface epithelium. Delicate collagen fibers admixed with ground substance are observed within ovarian medulla (M). Notice, normal density and distribution of collagen fibers around medullary blood vessels resemble those of the control.

Diabetic/Fennel Masson's trichrome x100

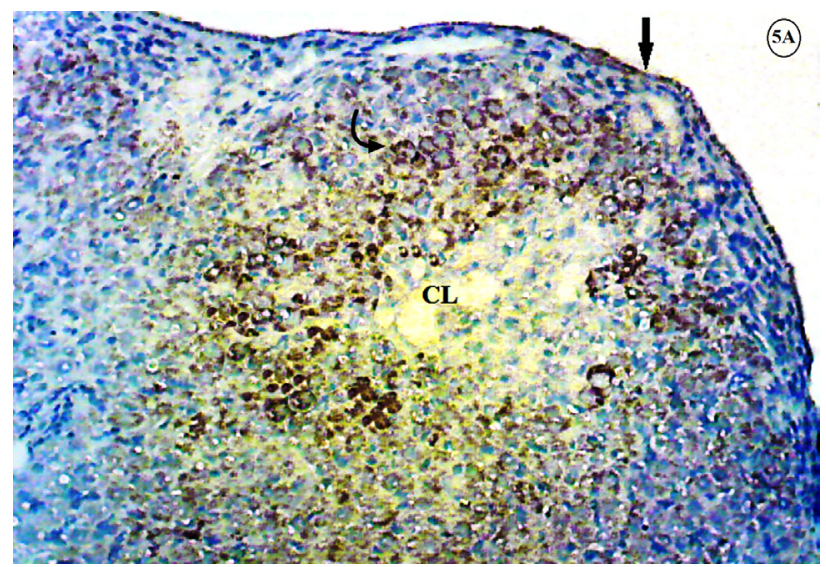

Fig. 5A: Showing strong brown cytoplasmic expression of ER $\alpha$ among the ovarian surface epithelium $(\boldsymbol{\downarrow})$ and granulosa lutein cells $(\hookrightarrow$ ) of corpus luteum (CL).

Control ER $\alpha$ immunohistochemical staining x200

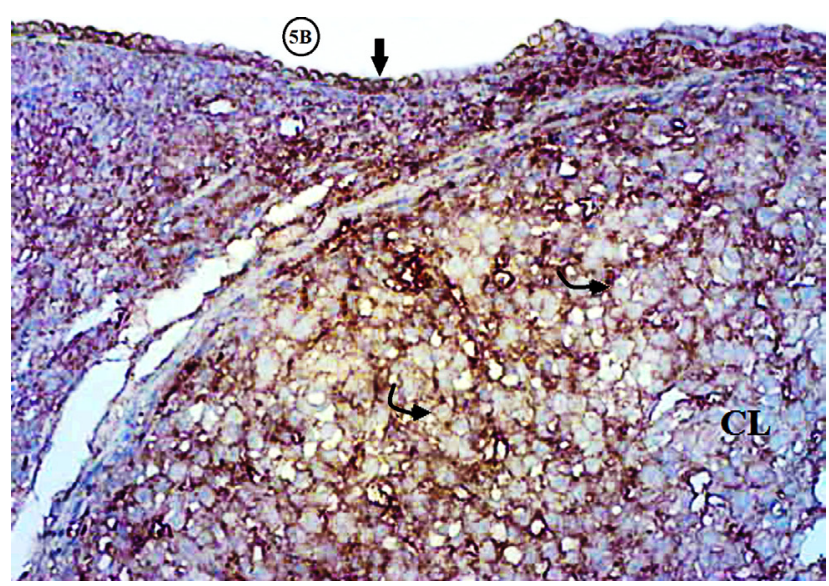

Fig. 5B: Showing cytoplasmic expression of ER $\alpha$ among the ovarian cubical surface epithelium ( $\downarrow$ ) and the granulosa cells $\leftrightarrow$ of corpus luteum (CL).

Fennel ER $\alpha$ immunohistochemical staining x200

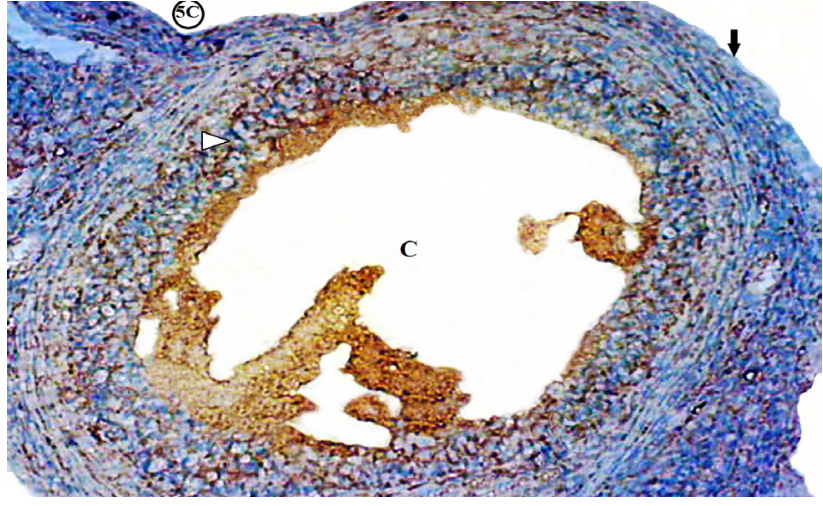

Fig. 5C: Showing weak cytoplasmic expression of ER $\alpha$ among the ovarian surface epithelium $(\downarrow)$ and the remaining of membrana granulosa cells $(\triangleright)$ of a follicular cyst $(C)$.

Diabetic ER $\alpha$ immunohistochemical staining x200

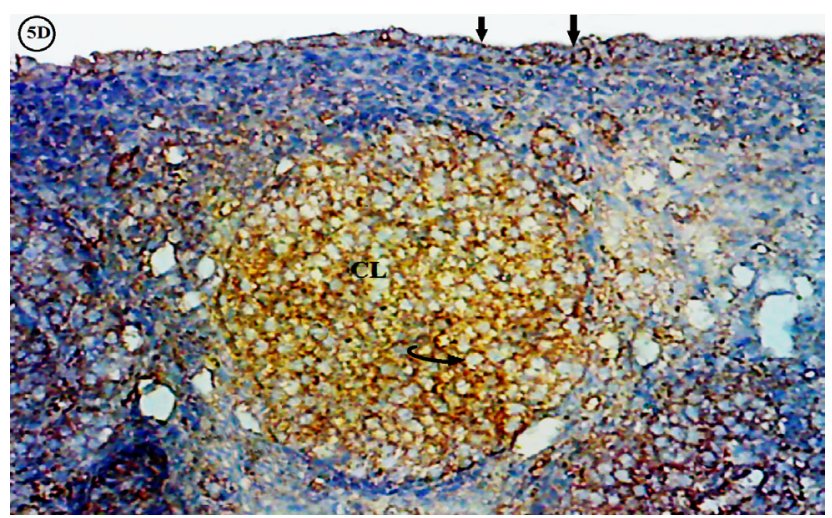

Fig. 5D: Showing restoration of the cytoplasmic expression of ER $\alpha$ among the ovarian surface epithelium $(\downarrow)$ and granulosa lutein cells $(\longrightarrow$ ) of corpus luteum $(\mathrm{CL})$.

Diabetic Fennel ER $\alpha$ immunohistochemical staining x200

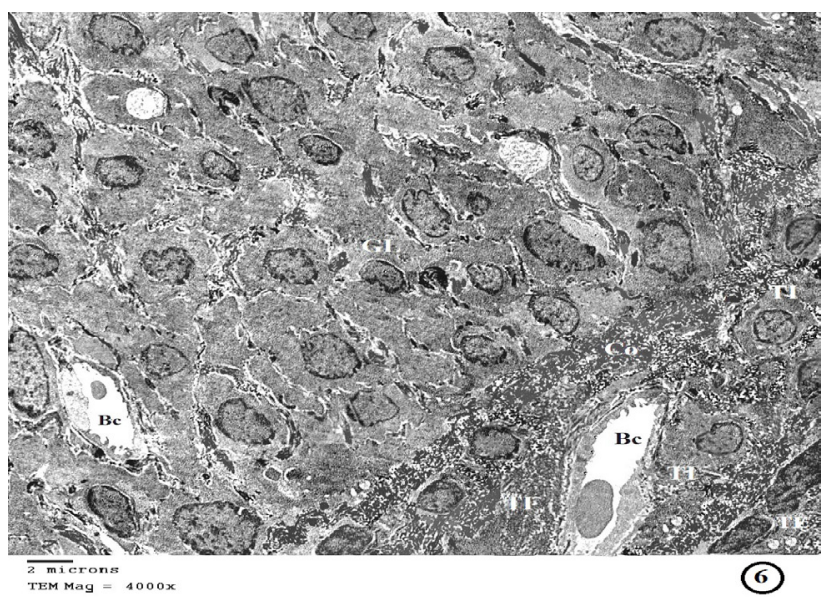

Fig. 6: Showing corpus lateum with large polyhedral granulosa lutein cells (GL) having indented euchromatic nuclei with blood capillaries (BC) in between them. Granulosa lutein cells are surrounded by polyhedral theca lutein interna cells (TI) having euchromatic oval nuclei enclosing blood capillaries in-between (BC) that contain red blood corpuscle. Notice, collagen fibers (Co) separating the granulosa lutein cells from each other and from the surrounding theca lutein interna cells.

Control- $\mathrm{x} 4000$ 


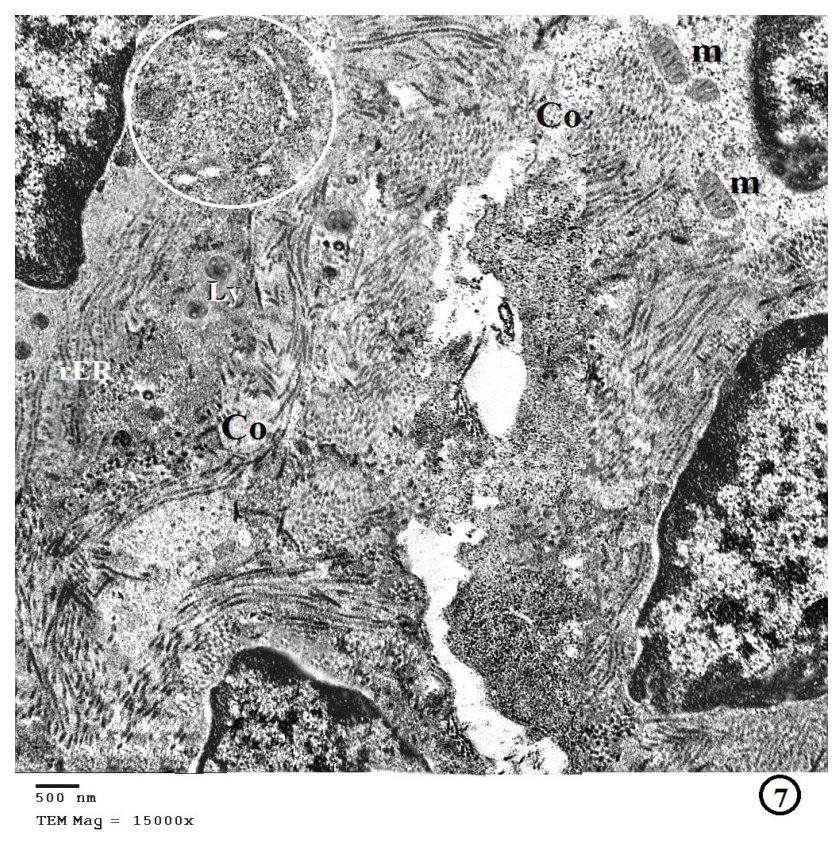

Fig. 7: Showing granulosa lutein cells containing mitochondria (m) with tubular cristae, lysosomes (Ly) as smooth-walled vesicles enclosed slightly electron-opaque material, parallel stacks of flattened cisternae of rough endoplasmic reticulum (rER) with lumina of relatively uniform size and Golgi complex (O) consists of stacked flattened saccules. Notice, cross and longitudinal sections of collagen fibers (Co).

Control-x15000

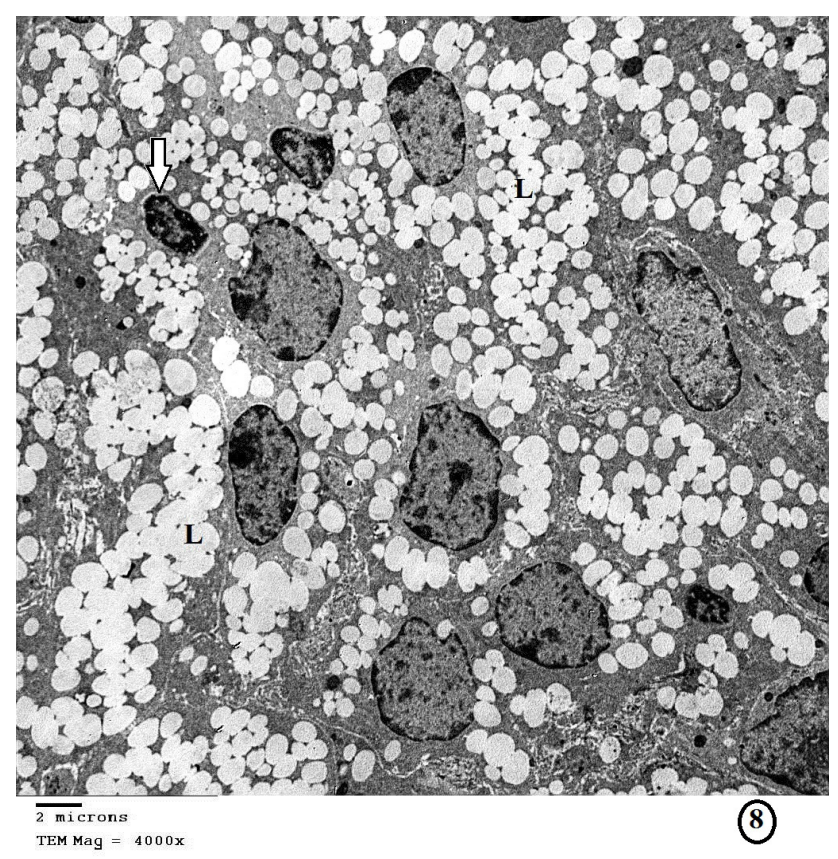

Fig. 8: Showing marked accumulation of numerous electron lucent lipid droplets (L) of variable sizes filling most of the granulosa lutein cells (GL) cytoplasm. Nuclei exhibit differences in size and shape. Some nuclei are shrunken and heterochromatic (V)

Diabetic -x4000

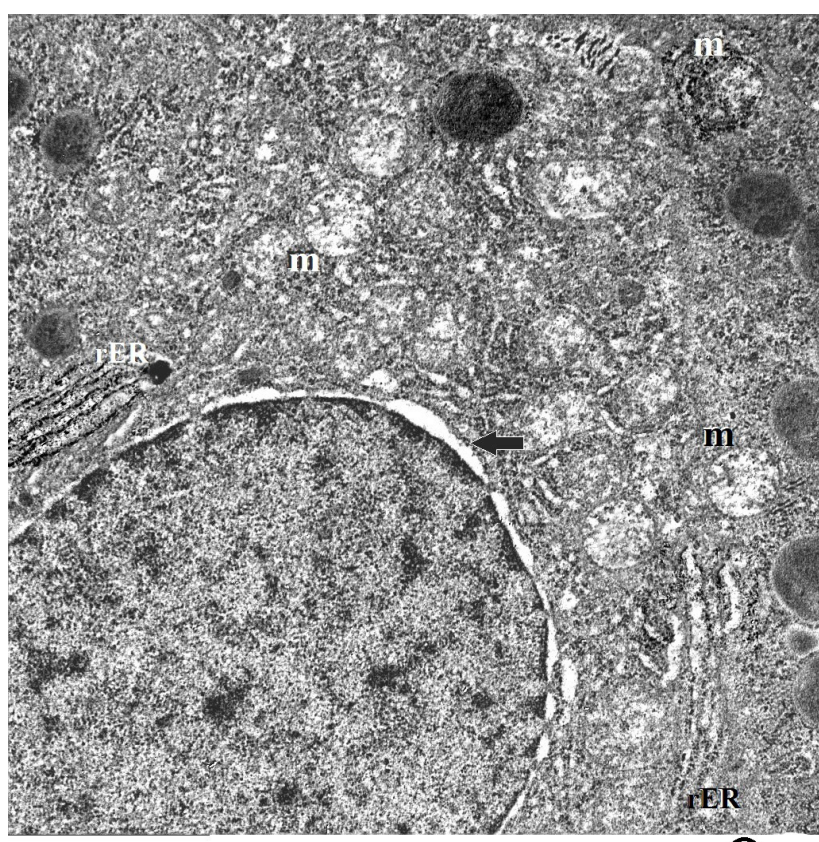

$\overline{500 \mathrm{~nm}}$

TEM Mag $=15000 x$

(9)

Fig. 9: Showing increase spacing of the nuclear envelope $(-)$, dilated cisternae of rough endoplasmic reticulum (rER), apparently abnormal degenerated mitochondria (m): irregular forms, swollen expanded with disrupted cristae and loss of their internal organization.

Diabetic-x15000

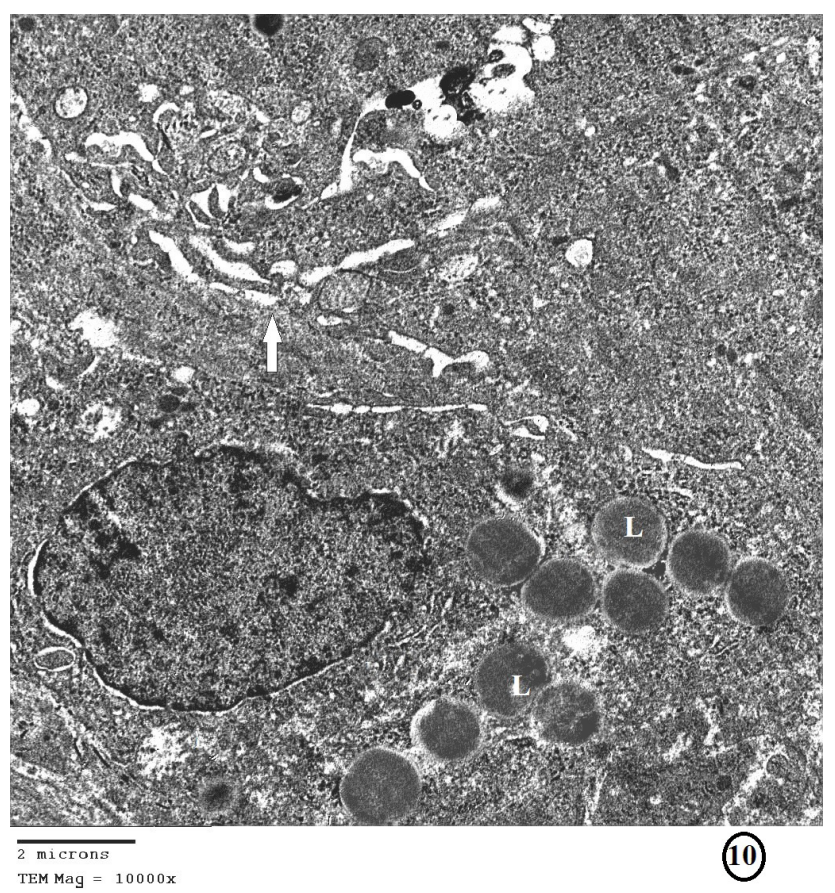

Fig. 10: Showing dilated Golgi complex in vesicular and tubular forms (U), and electron dense lipid droplets (L) of variable sizes in granulosa lutein cell' cytoplasm.

Diabetic- x10000 


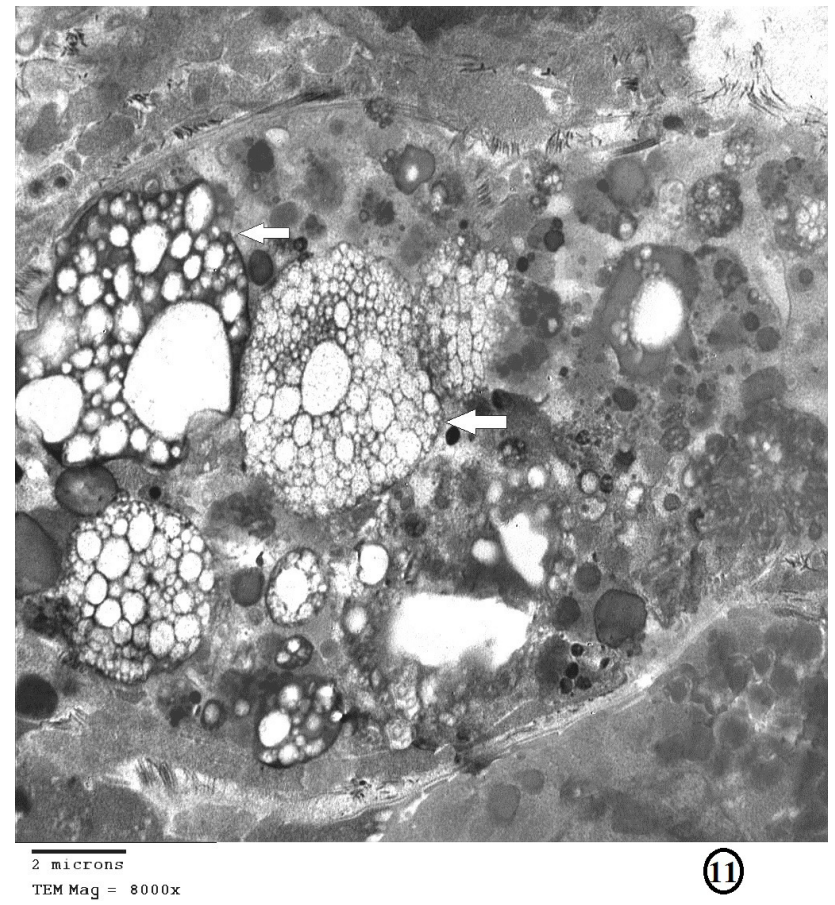

Fig. 11: Showing multivesicular bodies $(<)$ and closely packed smooth wall - bounded variable sized vesicles appear empty or enclosing electron opaque material within the luteal cell cytoplasm.

Diabetic-x8000

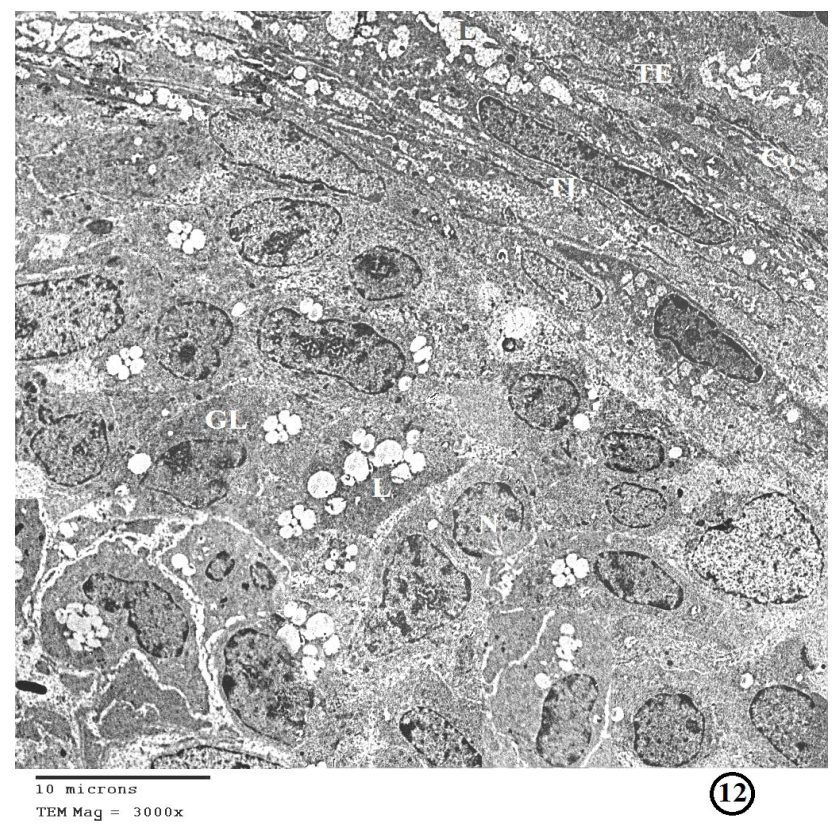

Fig. 12: Showing polyhedral granulosa lutein cells (GL) have euchromatic nuclei $(\mathrm{N})$ exhibit different sizes and shapes. Few variable sized electron lucent lipid droplets (L) scattered throughout the cytoplasm. Notice, theca lutein interna (TI) contains few lipid droplets with relatively euchromatic elongated flattened nuclei and flattened theca lutein externa (TE).

Diabetic/Fennel - x3000

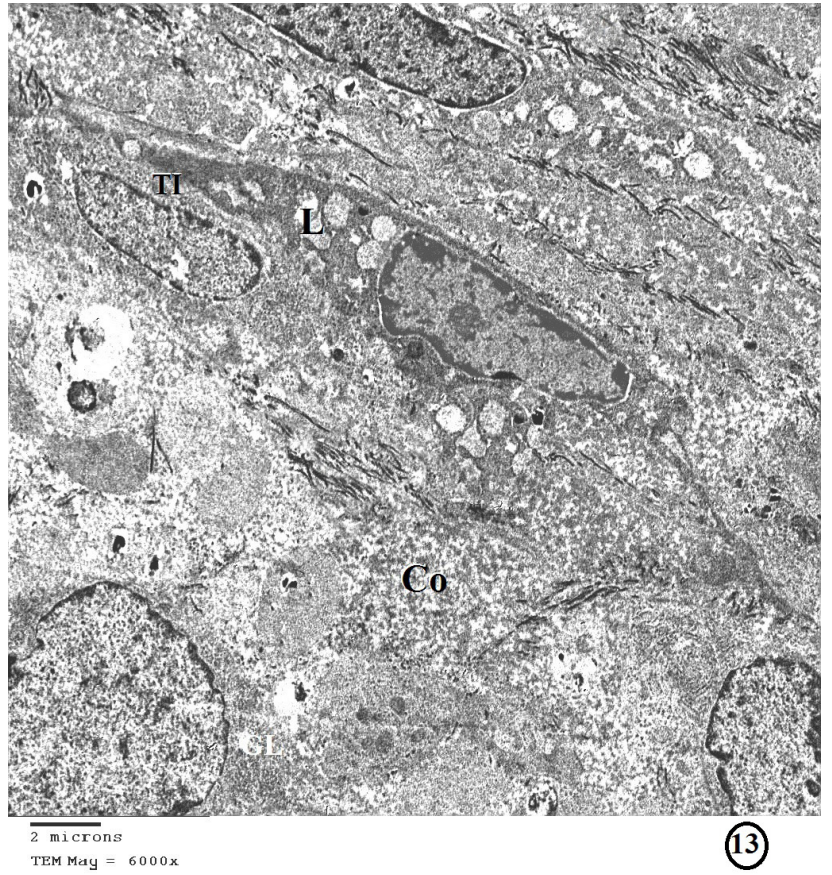

Fig. 13: Showing theca lutein interna (TI) contains variable sized electron lucent lipid droplets (L) and have elongated flattened nucleus. Cross and longitudinal sections of collagen fibers (Co) separate theca lutein interna from granulosa lutein cells.

Diabetic / Fennel -x6000

\section{DISCUSSION}

The ovary is one of the most important organs in the female reproductive system. It is an endocrine organ that undergoes aging by a continuous decreasing in the number of follicles, diminished quality of oocytes, menstrual irregularities and ovarian hormonal deficiency leading to subsequent menopause ${ }^{[22]}$.

There are some evidences that there is a strong association between aging, menopause, polycystic ovary (PCO) and its pathophysiological complications ${ }^{[23]}$.

Several evidences suggest that menopause status concomitant with more rapid progression of glucose intolerance, pathologic insulin resistant states and higher risk for developing type II diabetes leads to ovarian dysfunctions ${ }^{[24,25]}$. This prolonged hormonal and metabolic imbalance might be a defining, dangerous factor for polycystic ovarian syndrome (PCOS) $)^{[26]}$.

Foeniculum Vulgare Mill (fennel) and its products have attracted a great deal of interest among consumers and health care professionals for their potential benefits on human health ${ }^{[12]}$.

This research revealed that final body weight was significantly increased among fennel oil ingested rats (GII) and diabetic fennel oil ingested rats (GIV), which is in consistence with the work of Scarpace et al. ${ }^{[27]}$; 
Ley et al. ${ }^{[28]}$; Sangwan et al. ${ }^{[29]}$ who explained that there is a combination of both hormonal and neural changes that lead to obesity in postmenopausal female. As a consequence of menopause, there is hyperphagia, reduce clearance of triglycerides and thus there is increasing in serum triglycerides which can directly inhibit the transport of leptin across the blood brain barrier and contribute to the occurrence of leptin resistance across the central nervous system ending in an increase in body weight.

The reduction in body weight that was recorded among senile diabetic rats (GIII) is in agreement with DeFronzo and Tripathy ${ }^{[30]}$ who reported the association between insulin resistance in type 2 diabetes, elevated rates of lipolysis, increased plasma non-esterified fatty acids (NEFAs) and triglyceride concentrations with increased fat oxidation to compensate for diminished capacity for glucose uptake.

Our data on blood glucose levels showed a statistically significant increase in initial blood glucose level (3rd day after STZ intraperitoneal injection) among all STZ injected groups (GIII, IV) above $200 \mathrm{mg} / \mathrm{dl}$.

On the other hand, a marked improvement in final blood glucose level revealed at the end of the experiment (8th week) among all treated groups, fennel oil ingested rats (G II) and diabetic fennel oil ingested rats (GIV), when compared to rats of the diabetic group (GIII). The present study showed that reduction of blood glucose was more in (GII) compared to (GIV) at the same dose level of the fennel essential oil extract.

The antidiabetic effect of fennel essential oil is in agreement with previous researchers who noted the hypoglycemic action in various seed extract of foeniculum vulgare achieved by reducing intestinal disaccharides, high concentration of phytochemical constituents with the highest activity in scavenging superoxide radicals and other reactive oxygen species (ROS) generated during diabetes and lipid peroxidation inhibition via acting on both the cyclooxygenase and lipoxygenase pathways.

Our laboratory investigations on serum hormone levels; Estradiol (E2), Progesterone and Luteinizing Hormone (LH), showed that the least mean value of Estradiol and Progesterone levels, were recorded among diabetic rats (GIII) that showed at the same time higher mean value of serum LH. On the other hand, treated groups (GII, IV) showed significantly marked improvement of Estradiol and Progestron and LH levels when compared to rats of the diabetic group.

The disturbance in serum hormone levels, recorded in diabetic group (GIII), were due to the elevated androgen and estrogen levels over progesterone in insulin resistant diabetic women ${ }^{[35]}$.

Improvement of Estradiol, Progesterone and LH levels that were encountered in fennel oil treated rats $(G$ II, IV) is in accordance with Sadeghpour et al. ${ }^{[36]}$, who showed that fennel extract at a concentration of 100 and
$200 \mathrm{mg} / \mathrm{kg}$ can significantly increase the serum level of estrogen in mice in comparison to control groups. Besides, fennel has a long history as an estrogenic agent as it contains different ingredients such as anol or dimethylatedanethole, which may have some estrogenic activity.

The light microscopic results in diabetic animals (GIII) showed classically, polycystic ovaries (PCO) that contained numerous peripheral small antral follicles. The granulosa lutein cells of corpus luteum had a large accumulation of intracytoplasmic vacuoles and degenerated nuclei. These results were confirmed by the electron microscopic finding of presence of numerous lipid droplets. The most popular theories that have been put forward to explain the pathogenesis of PCOS in hyperinsulinemia is "selective insulin resistance" theory by Baillargeon and Carpentier ${ }^{[37]}$. They contributed insulin resistance, consequent hyperinsulinemia and glucose intolerance to hyperandrogenism which is the cardinal feature of PCOS. The intra-ovarian hyperandrogenism, promote the insulin growth factor (IGF)-I and IGF-I receptor gene expression that promote action of androgens on follicle growth. As the follicle enlarges, the granulosa cell layer that lines the follicle undergoing atresia, becomes apoptotic, progressively degenerative and dwindle in number and the entire structure gives rise to the appearance of a thin walled cyst predominantly located peripherally under a thickened capsule with a hypertrophied stroma.

Recent substantial theories have considered PCO as a chronic, low-grade inflammatory disorder in obese and nonobese diabetics. Hyperglycemia may result in increased reactive oxygen species (ROS) production and oxidative stress that contribute to inflammation in polycystic ovary syndrome (PCOS $)^{[38]}$. A long lasting status of over produced toxic free radicals and insufficient antioxidant activity associated with impaired mitochondrial function may contribute to a pro-inflammatory state with the subsequent activation of nuclear transcription factor-Kappa-B (NF-kB) that initiate inflammatory cascade that may be involved in reproductive disorders leading to sustained inflammatory status and progressive ovarian cystogenesis. Also, poor oocyte quality, oxidative deoxyribonucleic acid (DNA) damage of granulosa cells may predispose to apoptosis and play a pivotal role in the progression of ovarian cystogenesis and follicular atresia.

Increase the density and distribution of the collagenous fibers within the ovarian medulla of diabetic rats (GIII) is in agreement with Dhindsa et al. ${ }^{[39]}$, who stated that fibrosis is simply the consequences of inflammation that associated with excess production of reactive oxygen species (ROS), apoptosis dysregulation, increase levels of proinflammatory cytokines and mediators in the blood, such as tumour necrosis factor alpha (TNF- $\alpha$ ), C-reactive protein levels, tissue plasminogen activator (t-PA) levels, transforming growth factor alpha or beta (TGF- $\alpha$ or $-\beta)$ and increase the expression of multiple gene transcription factors such as activator protein-1 (AP-1) and nuclear 
transcription factor-Kappa-B (NF- $\kappa \mathrm{B})$ and decrease levels of anti-inflammatory cytokines.

Reduction in collagen distribution within ovarian medulla of the fennel oil treated rats (GIV, V) could be explained by Inoue et al. [40], who concluded that endogenous estrogen is a potent antioxidant, reduces spontaneous secretion of pro-inflammatory mediators by suppressing proinflammatory cytokines and lowering levels of procollagen type I, III and thus reduces collagen deposition and fibrosis. Sadeghpour et al. ${ }^{[36]}$; Khazaei et al. ${ }^{[41]}$; Sabzghabaee et al. ${ }^{[42]}$ added that the potent estrogenic effect that is involved in phytoestrogens of fennel oil provide anti-inflammatory protective role by acting on estrogen receptors, reduce inflammatory response, suppress early apoptosis, cell death and fibrogenesis.

In all ovarian samples, cytoplasmic expression of estrogen receptor alpha (ER $\alpha)$ that has been demonstrated by immunohistochemistry were positive in surface epithelial cells, luteinzed cells of the corpus luteum and granulosa cells as well as theca layers from all stages of studied follicular categories, even in remnant cells of follicular cysts.

Expression of ER $\alpha$ in the cystic follicles of our diabetic animals with polycystic ovary (PCO) correlates with a previous study of Scully ${ }^{[43]}$ who observed ER $\alpha$ immunoreactivity in the ovary remained without significant changes in their distribution and localization in animals with and without the polycystic disease. Noteworthy, Scully ${ }^{[33]}$ attributed ER $\alpha$ expression in PCO to chronically elevated circulating levels of luteinizing hormone that show a tendency to upregulate ER $\alpha$ together with increasing estrogen levels in the follicular fluid present in animals with this illness. However, there are no data available on the expression of ER $\alpha$ in cystic follicles and changes observed in cysts. More studies are necessary to fully understand and appreciate the implications of these observations.

The ovarian ultrastructural changes observed in diabetic rats (GIII) were in the form of numerous variable sized electron lucent and electron dense lipid droplets together with abnormally expanded and swollen mitochondria that appeared with disrupted crista losing its internal organization. Ruptured or expanded rough endoplasmic reticulum, dilated Golgi bodies were also encountered. Enlarged irregular nuclei, increase spacing of the nuclear membranes or even reduced nucleoplasm and shrunken nuclei were observed in group (III). Such findings are attributed to excess androgen and oxidative stress as most of these findings are the typical morphologic changes of all forms of hyperandrogenemea and highly activated steroidogenic cell[ ${ }^{[4]}$.

Another explanation of the mitochondrial abnormalities came from Yang et al. ${ }^{[45]}$, whereas oxidative stress played an important role in the pathogenesis leading to progressively degenerated mitochondria. They explained the mechanisms by the fact that oxidative stress alter bioenergetics and potentially increase reactive oxygen species (ROS) production.

The dilated rough endoplasmic reticulum observed in GIII is in agreement with Chen et al. ${ }^{[46]}$ who found that the abnormal number and shape of rough endoplasmic reticulum as a result of high accumulation of lipid droplets in the cytoplasm in association with damaged mitochondria may be related to androgen excess.

To our knowledge, there is no scientific data reported the histological effect of Foeniculum vulgare Mill (fennel) on the ovary. However, improvement in histological structure and ultrastructure of ovarian tissue that were encountered in the ovary of fennel oil consuming rats ( $\mathrm{G}$ II, IV, V) could be explained by the fact that fennel has an estrogenic effect. It contains different constituents which resemble stilbene and diethylstilbestrol, possessing estrogenic activity and providing protective role by acting on estrogen receptors increasing ovarian follicullogenesis in mice ovaries ${ }^{[36,41]}$.

\section{CONCLUSION}

Fennel essential oil could ameliorate diabetes. Besides, its folliculogenesis effect supported its use in folk medicine as a fertility enhancing agent.

\section{CONFLICT OF INTEREST}

There are no conflicts of interest.

\section{REFERENCES}

1. Kim, C.; Edelstein, S.L.; Crandall, J.P.et al. Menopause and risk of diabetes in the Diabetes Prevention Program. Menopause. Journal of The North American Menopause Society $2011 ; 18$ (8): 857-868.

2. Emanuela, F.; Grazia, M.; Marco, R.et al. Inflammation as a Link between Obesity and Metabolic Syndrome. Journal of Nutrition and Metabolism; Review 2012; 8(1):1-7.

3. Brown, R.E. and Kuk, J.L. Consequences of obesity and weight loss: a devil's advocate position.Obesity Reviews 2015; 16:77-87.

4. Edwin, E.; Sheeja, E.; Gupta, V.B. et al. Fight Diabetes the herbal way. A review . Express Pharma Lettre 2010; 1: 41- 48.

5. Pournaghi, P.; Sadrkhanlou, R.A.; Hasanzadeh, S. et al. An investigation on body weights, blood glucose levels and pituitary-gonadal axis hormones in 
diabetic and metformin-treated diabetic female rats. Veterinary Research Forum2012; 3 (2): 79-84.

6. Nguyen, T.H.; Nguyen, T.N.; Fischer. et al. Type 2 diabetes among Asian Americans: Prevalence and prevention. World J Diabetes 2015; 6(4):54.

7. Eshtiaghi, R.; Esteghamati, A. and Nakhjavani, M. Menopause is an independent predictor of metabolic syndrome in Iranian women. Maturitas 2010 ; 65 (3): 262-266.

8. Shifren, J.L. and Gass, M.L.S. The North American Menopause Society Recommendations for Clinical Care of Midlife Women Menopause 2014; 21(10):1-25.

9. Hosseinifar, S.; Erfanimajd, N.; Morovvati, H. et al. Diabetes $(\mathrm{db} / \mathrm{db})$ mutation-induced endometrial epithelial lipoapoptosis: Ultrastructural and cytochemical analysis of reproductive tract atrophy. American-Eurasian Journal of Toxicological Sciences 2010; 3 (3): 197-203.

10. Taylor, A.E.; McCourt, B.; Martin, K.A. et al. Determinants of abnormal gonadotropin secretion in clinically defined women with polycystic ovary syndrome. J Clin Endocrinol Metab.2010; 82(6): 2248-2256.

11. Maiorino, M.I.; Bellastella.G. and Esposito,K. Sexual function in women with type 2 diabetes: current perspectives. J Sex Med 2014; 7: 95-105.

12. Yang, W.; Lu, J.; Weng, J. et al. China National Diabetes and Metabolic Disorders Study Group. Prevalence of diabetes among men and women in China. N Engl J Med 2010; 362: 1090-1101.

13. Abou El-Soud, N.H.; El-Laithy, N.; El-Saeed, G.et al. Antidiabetic Activities of Foeniculum Vulgare Mill. Essential Oil in Streptozotocin-Induced Diabetic Rats Macedonian Journal of Medical Sciences $2011 ; 6(2)$ : 1-8.

14. Rivera, J.O.; Loya, A.M. and Ceballos, R. Use of Herbal Medicines and Implications for Conventional Drug Therapy Medical Sciences. Alternative and Integrative Medicine 2014; 3:2-6.

15. Abu Abeeleh, M.; Bani Ismail, Z.; Alzaben, K.R.et al. Induction of Diabetes Mellitus in Rats Using Intraperitoneal Streptozotocin: A Comparison between 2 Strains of Rats . European Journal of Scientific Research 2010; 32 (3): 398-402.

16. Elmlinger, M.W.; Kühnel, W. and Ranke, M.B. Reference ranges for serum concentrations of lutropin
(LH), follitropin (FSH), estradiol (E2), prolactin, progesterone, sex hormone-binding globulin (SHBG), dehydroepiandrosterone sulfate (DHEAS), cortisol and ferritin in neonates, children and young adults. Clin Chem Lab Med 2008; 40 (11): 1151-1160.

17. Bancroft, J.D. and Gamble, M. In: Theory and practice of histological Techniques, 6th edition. Churchill Livingstone, Edinburgh, London, Melbourne. 2007; 201-217.

18. Drury, R.A. and Wallington, E.A. Carleton's histological technique, 5th edition. Oxiford University Press. London, New York and Toronto. 1980; 139-142 and 182-184.

19. Williams, D.B. and Carter, C.B. Transmission Electron Microscopy. A Textbook for Materials Science. 2nd edition, Springer - Verlag. Berlin. Heidelberg, New York, London. 1996; 721-756.

20. Li, W.L.; Ren, G.; Huang, Y. et al. Mesenchymal stem cells: a double-edged sword in regulating immune responses. Cell Death and Differentiation 2012; 19 (3): 1505-1513.

21. Li, X.; Zhang, H.; Sheng, X.; Li, B.et al. Immunoreactivities of androgen receptor, estrogen receptors, p450arom, p450c17 proteins in wild ground squirrels ovaries during the nonbreeding and breeding seasons .Journal of Ovarian Research 2012; 5 (26): 2-10.

22. 22. Agarwal, A.; Aponte-Mellado, A.; Premkumar, B.et al. The effects of oxidative stress on female reproduction: a review. Reproductive Biology and Endocrinology 2012; 10 (49): 1477-1487.

23. Lobo, R.A. Metabolic syndrome after menopause and the role of hormones. Maturitas 2011; 60 (1): 10-18.

24. Choi, S.B.; Jang, J.S. and Park, S.L. Estrogen and exercise may enhance beta-cell function and mass via insulin receptor substrate 2 induction in ovariectomized diabetic rats. Endocrinology $2009 ; 146$ (21) : 4786-4794.

25. Rogers, N.H.; Witczak, C.A.; Hirshman, M.F.et al. Estradiol stimulates Akt, AMP-activated protein kinase (AMPK) and $\mathrm{TBC} 1 \mathrm{D} 1 / 4$, but not glucose uptake in rat soleus. Biochem Biophys Res Commun 2009; 382 (11) : 646- 650.

26. Moran, L.J.; Misso, M.L.; Wild, R.A. et al. Impaired glucose tolerance, type 2 diabetes and metabolic syndrome in polycystic ovary syndrome: a systematic review and meta-analysis. Hum. Reprod 2010; 16 (4): 332- 347. 
27. Scarpace, P.J.; Matheny, M.; Pollock, B.H. et al. Leptin increases uncoupling protein expression and energy expenditure. Am J Physiol Endocrinol Metab 2005; 273 (1 Pt 1): E226-E230.

28. Ley, C.J.; Lees, B. and Stevenson, J.C. Sex and menopause associated changes in body fat distribution. Am J Clin Nutr 2006 ; 55 (5): 950-954.

29. Sangwan, K.; Gupta, N.; Mehta, H.C. and Nanda, S. Effects of estrogen replacement therapy on serum lipid profile. Aust. Nz. J.Obestet. Gynaecol 2008 ; 43 (3): 213-219.

30. DeFronzo, R.A. and Tripathy, D. Skeletal Muscle Insulin Resistance Is the Primary Defect in Type 2 Diabetes . Diabetes Care 2009 ; 32 (2): S157-S163.

31. Faudale, M.; Viladomat, F.; Bastida, J.et al. Antioxidant activity and phenolic composition of wild, edible, and medicinal fennel from different mediterranean countries. J. Agric. Food Chem 2008 ; 56 (4): 1912-1920.

32. De Sousa, D.P. Analgesic-like Activity of Essential Oils Constituents. Molecules 2011; 16 (3): 2233-2252.

33. Shahat, A.A.; Ibrahim, A.Y.; Hendawy, S.F et al. Chemical composition, antimicrobial and antioxidant activities of essential oils from organically cultivated fennel cultivars. Molecules 2011 ; 16 (2): 1366-1377.

34. Bakkali, F.; Averbeck, S.; Averbeck, D. et al. Biological effects of essential oils. Food and Chemical Toxicology 2012; 46 (7): 446-475.

35. Gambineri, A.; Patton, L.; Altieri, P. et al. Polycystic ovary syndrome is a risk factor for type 2 diabetes: results from a long-term prospective study. Diabetes 2012; 61 (9): 2369-2374.

36. Sadeghpour, N.; Khaki2, A.A.; Najafpour, A.et al. Study of Foeniculum vulgare (Fennel) Seed Extract Effects on Serum Level of Estrogen, Progesterone and Prolactin in Mouse . Crescent J Med and Biol Sci 2015; 2 (1): 23-27.

37. Baillargeon, J.P. and Carpentier, A. Brothers of women with polycystic ovary syndrome are characterised by impaired glucose tolerance, reduced insulin sensitivity and related metabolic defects Diabetologia 2010 ; 50 (2): 2424-2432.

38. Rezvanfar, M. A. ; Ahmadi, A. ; Shojaei, H. A. et al. "Mechanistic links between oxidative/ nitrosative stress and tumor necrosis factor alpha in letrozole-induced murine polycystic ovary Biochemical and pathological evidences for beneficial effect of pioglitazone," Human \& Experimental Toxicology $2011 ; 31$ (9): 887-897.

39. Dhindsa, G.; Bhatia, R.; Dhindsa, M. et al. Insulin resistance, insulin sensitization and inflammation in polycystic ovarian syndrome. J Postgrad Med 2008; 50 (2): 140-144.

40. Inoue, H.; Shimizu, I.; Lu, G.; Itonaga, M.et al Idoxifene and estradiol enhance antiapoptotic activity through estrogenreceptor- $\beta$ in cultured rat hepatocytes Dig Dis Sci 2007 ; 48 (3): 570-580.

41. Khazaei, M.; Montaseri, A.; Khazaei, M.R.et al. Study of Foeniculum vulgare Effect on Folliculogenesis in Female Mice .Int J Fertil Steril 2011 ; 5 (3): 122-127.

42. Sabzghabaee, A.M.; Nili, F.; Ghannadi, A.et al. Role of menthol in treatment of candidial napkin dermatitis. World Journal of Pediatrics $2011 ; 7$ (1): 167-170.

43. Scully, R.E. Pathology of ovarian cancer precursors. J Cell Biochem 2009; 23 (2): 208-218.

44. Rabol, R.; Boushel, R. and Dela, F. Mitochondrial oxidative function and type 2 diabetes. Applied Physiology. Nutrition, and Metabolism 2012; 31 (4): 675-683.

45. Yang, Y.; Tsou, C.S.; Lee, T.C.; Wu, W.J. et al. Distribution of 127 edible plant species for antioxidant activities by two assays. J Sci Food Agric 2013; 86 (13): 2395-2403.

46. Chen, Q.; Sun, X.; Chen, J.et al. Direct rosiglitazone action on steroidogenesis and proinflammatory factor production in human granulosa-lutein cells. Reprod Biol Endocrinol 2009; 7: 147-154. 
الملخص العربى

التغيرات النسيجية للمبيض الناجمة عن تناول الثمر في الجرذ المسن المصاب بداء السكري

حكمت أحمد سرور، فاطمة سبا عبد العال، منى محمد عبد الجليل

$$
\text { قسم الهستولوجيا ـ كلية طب (بنات) الأزهر- القاهرة - مصر }
$$

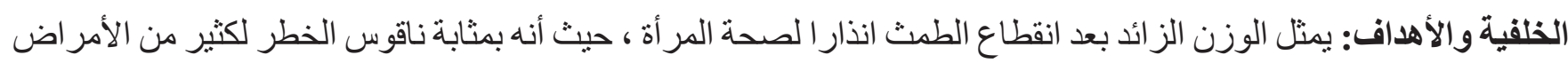

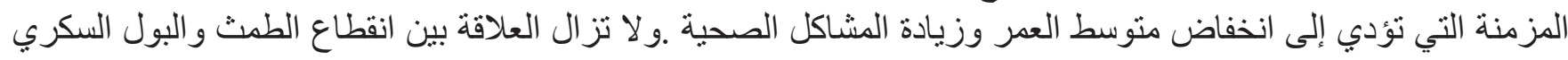

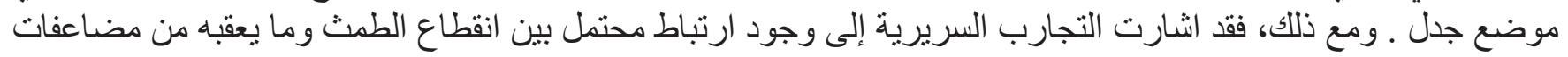

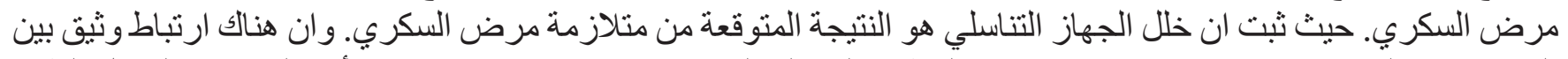

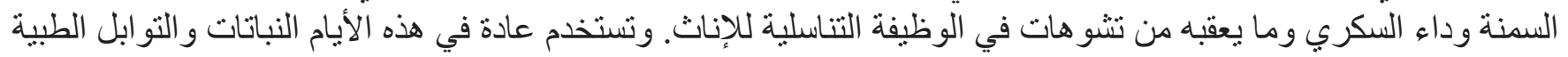

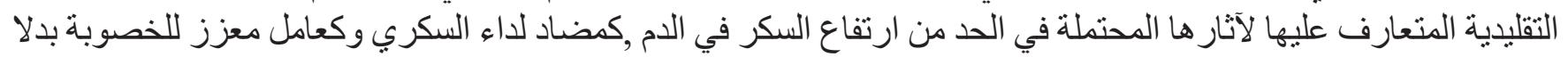

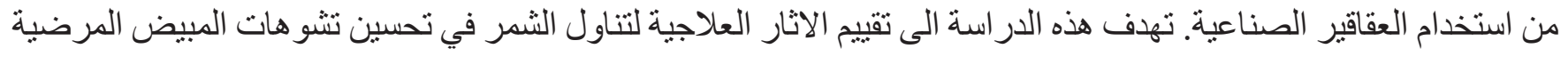

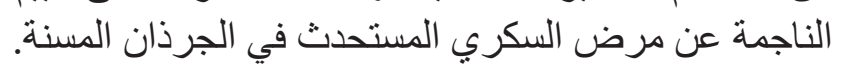

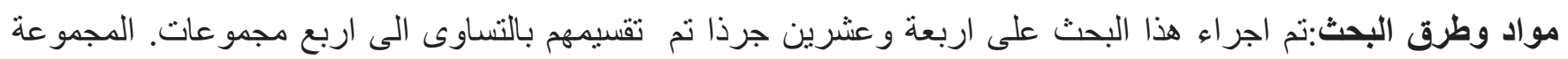

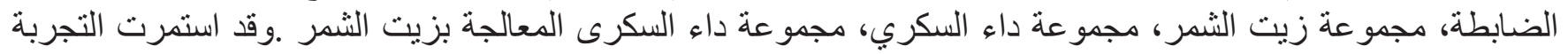

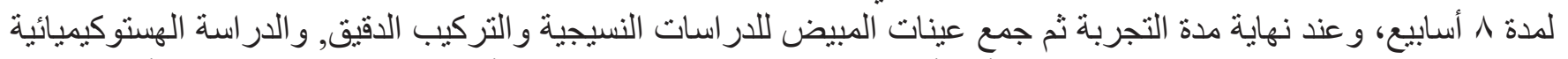

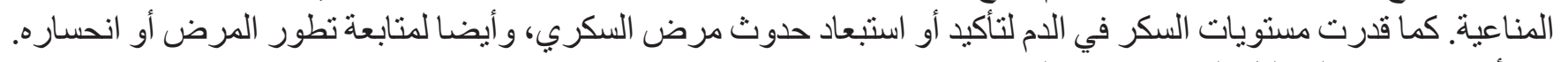

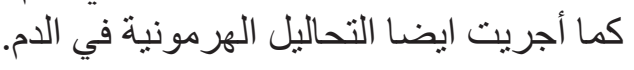
النتائج : أظهرت نتائج الفحص المجهري تكيس المبايض حيث احتوت المبايض المبايض على العديد العبد من الجريبات في مجموعة داء

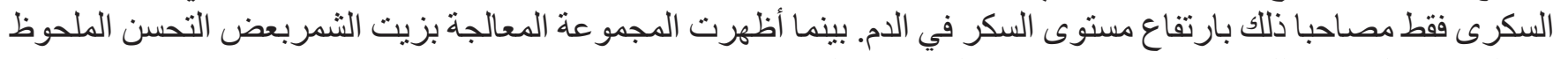

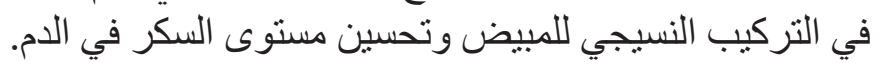

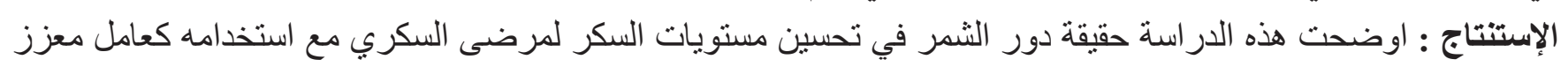

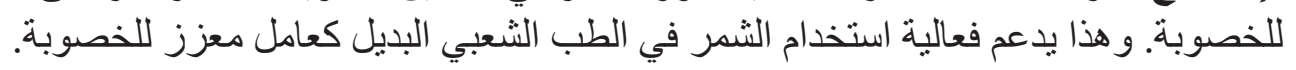

